ISSN: 0213-2079 - ISSN electrónico: 2386-3889

DOI: https://doi.org/10.14201/shhmo201638255105

\title{
EL NOVIAZGO EN LA ESPAÑA MODERNA Y LA IMPORTANCIA DE LA «PALABRA». TRADICIÓN Y CONFLICTO*
}

\section{Engagements in Early Modern Spain and the Importance of the "Promise». Traditions and Conflits}

\author{
Marta RUIZ SASTRE \\ Universidad de Huelva \\ Correo-e: marta.ruiz@dhis2.uhu.es \\ María Luisa CANDAU CHACÓN \\ Universidad de Huelva \\ Correo-e: candau@dhis2.uhu.es
}

RESUMEN: Este trabajo analiza la fuerza de los esponsales en la sociedad occidental durante los Tiempos Modernos. La palabra de casamiento, sin estar revestida de carácter sacramental, ni ser requerida formalmente para la celebración del matrimonio canónico, generaba en el ideario colectivo un vínculo difícilmente destructible. La promesa intercambiada obligaba a los implicados a mantener firme su ofrecimiento hasta el acto mismo del casamiento. Así aparecía recogido en la legislación moderna-eclesiástica y secular-y así sería respaldada en la opinión popular. Ni el concilio de Trento ni las instituciones eclesiásticas - pese al decreto Tametsi- lograron evitar la pervivencia de su significado, y la práctica común mantendría su valor adaptando a la realidad cotidiana la esencia del sacramento: la expresión del libre consentimiento y su consumación mediante «trato carnal». El estudio

* Trabajo efectuado al amparo de los proyecto de investigación I+D HAR2012/37394: Las mujeres y las emociones en Europa y América. Discursos, representaciones, prácticas. Siglos XVII-XIX. La vida emocional de las mujeres: experiencias del mundo, formas de la sensibilidad. Europa y América, 1600-1900. HAR2015/63804-P.

(C) Ediciones Universidad de Salamanca / ®@ Stud. his., H. ${ }^{a}$ mod., 38, n. 2 (2016), pp. 55-105 
MARTA RUIZ SASTRE Y MARÍA LUISA CANDAU CHACÓN

EL NOVIAZGO EN LA ESPAÑA MODERNA Y LA IMPORTANCIA DE LA «PALABRA». TRADICIÓN Y CONFLICTO

de las demandas por incumplimiento de promesa de matrimonio refleja la pervivencia de una práctica social antigua y revela parte del entramado histórico del proceso matrimonial.

Palabras clave: Historia del matrimonio; esponsales; noviazgo.

\begin{abstract}
The present work studies the strength that betrothals had in Western society during Modern Times. Even without having a sacramental nature and without being formally required for the celebration of a religious ceremony, the betrothal created in the collective mind a bond that was difficult to break. The promisethat was exchanged forced those who were involved to stay true to it until the very act of marriage. This appeared in this way in modern-ecclesiastical and secular-legislation, and it would be thus supported by popular opinion. Neither the Council of Trent nor the ecclesiastical institutions -despite the decree Tametsi- managed to avert the continued existence of its meaning, and common practice would continue to keep its value, adapting the spirit of the sacrament to everyday reality: the expression of free consent and its consummation through «carnal knowledge». The analysis of lawsuits for breach of promise of marriage reflects the persistence of an old social practice and reveals part of the historical scheme of the marriage process.
\end{abstract}

Key words: History of Marriage; Betrothals; Engagment.

1. INTRODUCCIÓN: EL DERECHO CONSUETUDINARIO, LOS ESPONSALES Y EL PODER LA «PALABRA» DE MATRIMONIO

La fuerza de los esponsales en la sociedad occidental viene dada fundamentalmente por su significación cultural. La palabra de casamiento, sin estar revestida de carácter sacramental, ni ser requerida formalmente para la celebración del matrimonio canónico, generaba en el ideario colectivo un vínculo difícilmente destructible entre quienes hacían uso de ella. La promesa intercambiada obligaba a los implicados a mantener firme su ofrecimiento hasta el acto mismo del casamiento. Así aparece recogido en la legislación moderna -eclesiástica y secular-y así sería respaldada en la opinión popular.

Todo su andamiaje teórico sentaba las bases en los códigos legislativos romanos y germánicos ${ }^{1}$. No obstante, no se contará con una definición precisa de los esponsales

1. Sobre legislación visigoda véase García GonZÁlEZ, J.: «El incumplimiento de las promesas de matrimonio en la Historia del Derecho español», Anuario de Historia del Derecho español,

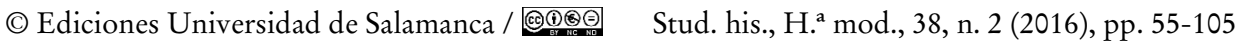


MARTA RUIZ SASTRE Y MARÍA LUISA CANDAU CHACÓN

EL NOVIAZGO EN LA ESPAÑA MODERNA Y LA IMPORTANCIA DE LA «PALABRA». TRADICIÓN Y CONFLICTO

hasta los siglos XII y XIII, tiempos de renacimiento intelectual de la teología y de importantes aportaciones del Derecho Canónico. El sistema matrimonial hasta entonces se había sustentado en una teoría muy simple: para contraer matrimonio bastaba con que las partes manifestaran por medio de palabras -o signos equivalentes- su conformidad; consentimiento emitido por los esposos en el momento de iniciar la vida en común conocido bajo la denominación de sponsalia per verba de praesenti ${ }^{2}$. No obstante, existía también en el derecho y en la mentalidad popular otro consentimiento precedente -y que ahora nos ocupa-, denominado sponsalia per verba de futuro, entendido -a priori- como paso preparatorio para las nupcias. En la práctica resultaron habituales la aceptación y validez de tales matrimonios una vez verificada la commixtio sexus entre los «desposados para casar». El verdadero vínculo, perfecto e indisoluble, solo era factible -a ojos de muchos- mediante la entrega mutua de los cuerpos.

¿Qué valor debía darse, pues, a la desponsatio? ¿Se trataba de una simple promesa de casamiento futuro o, por el contrario, refería directamente la formalización de un pacto matrimonial? La cuestión estaba investida de una gran trascendencia, pues del significado que se le diera al término dependía la consideración -o no-de la promesa como matrimonio y la viabilidad de su disolución. La producción de los teólogos medievales sería decisiva a la hora de encontrar una solución al problema. A ellos debemos la tajante diferenciación entre compromiso y matrimonio, reservando el carácter sacramental e indisoluble para el segundo, único que representaría plenamente -a su entender- la unión de Cristo con su Iglesia.

Así, las teorías de mayor alcance llegarán a mediados del siglo XII, cuando Graciano y Pedro Lombardo, máximos exponentes de las escuelas de Bolonia y París, elaboran sus respectivas conclusiones sobre la formación del vínculo. Graciano (Decretum, 1140-1142) concebirá el matrimonio como un "proceso», compuesto por la promesa, como fase inicial, y la consumación, como etapa concluyente. Pocos años después, Pedro Lombardo (Quatur libri sententiarum

23, 1953; Lozano Corbi, E. A.: «Los esponsales en el Derecho Romano», Anales. Anuario del centro de la UNED de Calatayud, 1, 1993, pp. 145-154; GAUDEMET, J.: El matrimonio en occidente. Madrid, 1993, pp. 40-54; GARCÍA SÁNCHEZ, J.: «Incumplimiento de esponsales: de Roma al derecho vigente», en López Rosa, R.; Pino Toscano, F. (Coords.): El derecho de familia de Roma al derecho actual. Huelva, 2004, pp. 225-270.

2. La Iglesia recomendaba que los fieles dieran este consentimiento en público (in facie ecclesiae), haciendo intervenir en la unión a un sacerdote, aunque la falta de esta solemnidad no acarreaba la nulidad del acto. Los sponsalia de praesenti constituían, en principio, una unión legítima, aunque no adquirían su perfección hasta que se consumaran con la copula carnalis. Hasta ese momento, el matrimonio era susceptible de disolución en algunos supuestos extraordinarios. 
MARTA RUIZ SASTRE Y MARÍA LUISA CANDAU CHACÓN

EL NOVIAZGO EN LA ESPAÑA MODERNA Y LA IMPORTANCIA DE LA «PALABRA». TRADICIÓN Y CONFLICTO

ca. 1152) defenderá el consentimiento expresado, efectivo y actual de los esposos, como causa eficiente del matrimonio. En otras palabras, a los verba de praesenti Lombardo opondrá los verba de futuro -identificados con los esponsales romanos-, no siendo más que la promesa de contraer matrimonio, y no formando, en consecuencia, parte del mismo. Tesis que vendrían a ser apoyadas en la segunda mitad del siglo por el pontífice Alejandro III, marcando el triunfo de las propuestas consensualistas como esencia del matrimonio. Un matrimonio que aún (habría de esperar hasta el siglo xv) no era considerado dogmáticamente como sacramento.

Triunfo del consensualismo pero ¿cómo había de significarse el consentimiento? Las contribuciones de canonistas posteriores (Huguccio), y la persistencia de las citadas, apuntaban la existencia de un verdadero vínculo conyugal mediando promesa de matrimonio y trato sexual posterior, naciendo el vínculo en razón de la conformidad dada para la cópula -que actuaría así como un consentimiento de presente-, y no de los esponsales en sí. Admitirán esta interpretación los pontífices posteriores Inocencio III (1198-1216) y Gregorio IX (1227-1241), siguiendo la tendencia marcada por la mayor parte de los teólogos de su tiempo, estableciendo de forma teóricamente definitiva la distinción entre los esponsales (la promesa de contraer), y el matrimonio de presente (la contratación efectiva).

El concilio de Trento (1545-1563) no aportaría novedades para sistematizar los esponsales. Los padres conciliares procuraron imponer la celebración pública de los matrimonios, pero nada expresaron respecto al momento del intercambio de las palabras de casamiento. Vistas como un elemento carente de espiritualidad, y de carácter privado entre las partes, fueron relegadas a un segundo plano. No obstante, la tradición había convertido a la «palabra» en una fase preparatoria del matrimonio de suma importancia, dado que, efectuado libremente por las partes a una edad no inferior a siete años, obligaba a los contrayentes a respetar el contrato. Solo en caso de que interviniesen motivos particularmente graves podría abandonarse la promesa -en su delimitación intervinieron autores morales de la talla de Francisco de Ledesma, Tomás Sánchez, Jaime Corella, Daniel Concina o Murillo Velarde- $-^{3}$, y en tal caso era conveniente la intervención de un juez que actuase a favor de la parte afectada.

3. El derecho canónico determina la licitud de la disolución en los siguientes supuestos: cuando, por mutuo consentimiento, los dos prometidos consienten en anular la obligación; en caso de que uno de los prometidos -o los dos- opten por no contraer matrimonio e ingresar en religión (siempre que no se hubieran mantenido relaciones sexuales); cuando uno de los prometidos contrae matrimonio con otra persona, sin permiso de la primera; cuando se pacta, en el momento del otorgamiento recíproco, una fecha concreta para la celebración del matrimonio y cumplido el plazo alguna de las partes se niega a hacerlo, o cuando tiene lugar el alejamiento físico prolongado de la pareja; por causa grave sobrevenida, entre las que

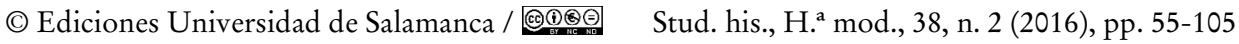




\section{MARTA RUIZ SASTRE Y MARÍA LUISA CANDAU CHACÓN EL NOVIAZGO EN LA ESPAÑA MODERNA Y LA IMPORTANCIA DE LA «PALABRA». TRADICIÓN Y CONFLICTO}

Muchas fueron las cuestiones que quedaron pendientes en torno a los esponsales. En los siglos que sucedieron a Trento gran parte de la conflictividad matrimonial se concentrará en la desatención de la promesa y en la confusión resultante de la identificación establecida entre las palabras de casamiento y el matrimonio presunto, es decir, aquel supuestamente contraído al mantener relaciones sexuales los desposados para casar. Cierta imprecisión respecto al tema contenida en los decretos tridentinos, unida a la lenta penetración de la norma conciliar, favorecieron la aparición de los conflictos.

Esponsales, palabras de futuro, palabras de presente, matrimonios presuntos... conceptos que, independientemente de la teología, de los textos de los canonistas o de las sesiones de los concilios, representaban, por la tradición y para el común de la sociedad, una única cosa: el proceso de legitimación de la unión.

\section{Noviazgo y PROMESA: ALgunAS PERSPECTIVAS DE ESTUdio. LAS CONSECUEN- CIAS DE TRENTO}

Los estudios referentes a la historia de la familia demostraron su vitalidad en los campos de la demografía histórica, la antropología social, la historia económica y la historia social. En realidad, como nudo y marco de confluencia de las actividades humanas, en su primera instancia, la familia engloba todas las variables históricas anejas a la vida, enmarcando su propio curso. En el corazón, su origen: el matrimonio, entendido aquel no solo metafóricamente; aquí la cuestión de las emociones -identificables, o no, con los sentimientos o los amores- tendrán también qué decir en el proceso histórico de constitución familiar. A fin de cuentas, la historia de los sentimientos, de su «modelaje» o educación, y de las relaciones entre hombres y mujeres, no se forjó totalmente al margen de las instituciones, independientemente de sus identificaciones, lícitas o no. De modo que -ella

\footnotetext{
se menciona la mudanza en los bienes de fortuna de los desposados, el cambio radical en la belleza de la mujer, la fornicación de los contrayentes con terceras personas, o cualquiera de los supuestos contemplados por la ley para proceder al divorcio de los casados o para declarar nulo un matrimonio; en caso de existencia de alguna condición personal grave desconocida antes de celebrarse los esponsales; o caso de que estos no cumpliesen los requisitos necesarios para su validación (libertad de decisión, pleno conocimiento del paso dado y mutua promesa de casamiento). Existe diversidad de opiniones sobre otros supuestos, como el de voto simple de castidad sin intención de ingresar en religión. Sobre la regulación jurídica de la ruptura de los esponsales recogida en los manuales de los siglos modernos, Macías Domínguez, A. M.: El matrimonio, espacio de conflictos: incumplimiento de palabra, divorcio y nulidad en la Archidiócesis Hispalense durante el siglo XVIII, Tesis doctoral inédita. Universidad de Huelva, Departamento de Historia II y Geografía, 2014.
}

(C) Ediciones Universidad de Salamanca / ®@ Stud. his., H. ${ }^{a}$ mod., 38, n. 2 (2016), pp. 55-105 
MARTA RUIZ SASTRE Y MARÍA LUISA CANDAU CHACÓN

EL NOVIAZGO EN LA ESPAÑA MODERNA Y LA IMPORTANCIA DE LA «PALABRA». TRADICIÓN Y CONFLICTO

también- constituirá una faceta más entre los acercamientos interdisciplinares incorporados a la Historia familiar ${ }^{4}$.

No recorreremos aquí las numerosas aportaciones nacidas desde tantos ámbitos, habida cuenta su amplitud, remitiéndonos a obras y artículos donde se aborda más concreta y prolijamente un estado de la cuestión ${ }^{5}$. Sí nos centraremos en las investigaciones concernientes al proceso de formación, a las «negociaciones» del matrimonio, entendidas estas como acuerdos en su sentido más amplio: los «tratos» para su formalización (no tanto de negocios y dotes como, sobre todo, de «cuerpos»), las promesas para realizarlo, los medios para asegurarlo o las fórmulas de sustraerse a un supuesto compromiso, a veces notorio, a veces público; a veces, también refrendado únicamente en la intimidad de un consentimiento carnal sin más testigos que -como en la literatura- los cielos o los santos. El poder de la «palabra» tal como ha sido señalado aquí por una tradición romana y germánica y posteriormente canónica, y los intentos por asegurarla o esquivarla, ante los tribunales de justicia, ha motivado el interés de los historiadores de los últimos años, manifestando ser trayectoria de una gran vitalidad, al calor no tanto de la propia historia de la institución familiar, cuanto de la derivada del conflicto y sus resoluciones, así como de la historia de la vida cotidiana, un espacio (físico y temporal) en donde los enfrentamientos se materializan, cargados de violencia, simbólica y, como sabemos, también material. Para resolverlos, de fracasar los intermediarios o el arbitraje de quienes han sido llamados -en todo tipo de conflictos- agentes infra-judiciales ${ }^{6}$, se hallaban los mencionados tribunales de

4. Un ejemplo, el monográfico coordinado por Morant Deusa, I. y Bolufer Peruga, M.: «El matrimonio en el corazón de la sociedad», Tiempos Modernos, 2009.

5. Gómez Carrasco, C. J.: Familia y capital comercial en la Castilla meridional. Madrid, 2009. Esencialmente el capítulo VII. García GonzÁlez, F. (Coord.): La Historia de la familia en la Peninsula Ibérica, balance regional y perspectivas. Albacete: Universidad de Castilla la Mancha, 2008. Chacón Jiménez, F. y Bestard, J. (Coords.): Familias. Historia de la sociedad española (del final de la Edad Media a nuestros días). Madrid, 2011 Fruto de la expansión de la Demografía Histórica y, posteriormente, del nacimiento del seminario de Historia Social de la Población, las Universidades de Murcia y Castilla la Mancha, como es sabido, han desarrollado durante años las principales aportaciones en estas líneas de investigación. También en Monzón Perdomo, M. E.: «La familia como espacio de conflicto. Los juicios por disenso matrimonial en Tenerife», Anuario de estudios Atlánticos, 60, 2014, pp. 413-450. Ramos Cobano, C.: La familia en femenino. Prácticas sociales y relaciones de género entre los Cepeda en el tránsito a la Contemporaneidad. Madrid, FEHM, 2016 (En prensa).

6. Mantecón Movellán, T. A.: «Desviación, disciplina social e intervenciones judiciales en el Antiguo Régimen», Studia historica. Historia Moderna, 14, 1996, pp. 223-248; Conflictividad $y$ disciplinamiento social en la Cantabria rural del Antiguo Régimen. Santander, Universidad de Cantabria - Fundación Marcelino Botín, 1997; «El mal uso de la justicia en la Castilla del siglo xviI», en Fortea, J. I., Gelabert, E. y Mantecón, T. A. (Coords.): Furor et rabies.

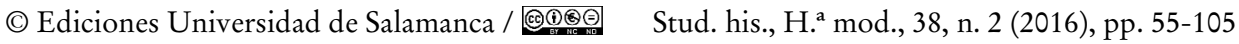


MARTA RUIZ SASTRE Y MARÍA LUISA CANDAU CHACÓN

EL NOVIAZGO EN LA ESPAÑA MODERNA Y LA IMPORTANCIA DE LA «PALABRA». TRADICIÓN Y CONFLICTO

justicia, civiles o eclesiásticos, al ser entendidos tales problemas como asuntos de fuero mixto, como correspondía a las cuestiones tocantes al sacramento del matrimonio (como tal desde el Concilio de Florencia, 1438, luego regulado en Trento) y -obviamente por la confesionalidad de los Estados y la vigencia del derecho- al orden de la sociedad.

Partiendo de aportaciones clásicas, fueran desde el Derecho, la Antropología o la Historia ${ }^{7}$ los intereses de los historiadores sobre el proceso matrimonial (palabras de futuro, esponsales, palabras de presente, velaciones, bendiciones públicas) han prestado atención esencialmente a la concertación de los matrimonios y a lo que tales «negocios» posibilitaron. Con mayor especificidad en los entresijos nobiliarios y de grupos de la élite, por huellas (notariales), relevancia, continuidad de redes o salvaguarda de patrimonios. Pero las posibilidades del estudio del proceso para el historiador de lo social y del entramado emocional que ello podía suponer han sido enormes; aunque su rastro se manifieste, por lógica y nuevamente, en la documentación generada en el conflicto. Las palabras de futuro, la promesa de matrimonio, la supuesta intencionalidad de contraer las nupcias -por lo mismo su consumación-, su posterior (y muchas veces avisado ${ }^{8}$ ) incumplimiento, los también más que probables embarazos, la prole consecuente, las demandas por

Violencia, conflicto y marginación en la Edad Moderna. Santander, Universidad de Cantabria, 2002; Seidel Menchi, S., Quaglioni, D. (Dirs.): Matrimoni in dubbio. Unione controverse e nozze clandestine in Italia dal XIV al XVIII secolo. Bolonia, Il Mulino, 2001; Transgressioni. Seduzione, concubinato, adulterio, bigamia (XIV-XVIII secolo). Bolonia, Il Mulino, 2004; «La Svoltadi Trento. RicercheItaliane sui processimatrimoniali», Popolazione e Storia, 2, 2004, pp. 21-31; I tribunali del matrimonio (secoli XV-XVIII). Bolonia, Il Mulino, 2006; LomBARDI, D.: Storia del Matrimonio. Bolonia, Il Mulino, 2008; Macías Domínguez, A. M.: «Conflictividad matrimonial en el Arzobispado de Sevilla durante la Edad Moderna (siglo xviII)», en JimÉnez Estrella, A.; Lozano Navarro, J. (Eds.): Actas de la XI Reunión Cientifica de la Fundación Española de Historia Moderna. Granada, Universidad de Granada, 2012, pp. 474-486; Macías Domínguez, A. M.: «La conflictividad matrimonial bajo control. La intermediación de la comunidad como agente de resolución de conflictos entre casados. Sevilla, siglo XVIII», en IGLESIAS Rodríguez, J. J., Pérez García, R., Fernández Chaves, M. (Eds.): Comercio y cultura en la Edad Moderna. Actas de la XIII Reunión Científica de la Fundación Española de Historia Moderna. Sevilla, Universidad de Sevilla, 2015.

7. Gaudemet, J.: Le mariage en Occident: les moeurs et le droit. París, 1987 (hay trad. al castellano); Goody, J.: L'Évolution de la famille et du mariage en Europe. París, 1985 (1 $1^{\mathrm{a}} \mathrm{ed}$. 1983); Goody, J.: La famille en Europe. París, Seuil, 2001; Casey, J.: Historia de la familia. Madrid, Espasa Calpe, 1990; Familia, poder y comunidad en la España moderna. Valencia, 2009.

8. Con tales términos -Avisos- se editaron libros en el Quinientos y Seiscientos, en Inglaterra (Advice's Books) y España. Los avisos a doncellas que alertaban de la invalidez, tras Trento, de los matrimonios clandestinos, son un clásico de la Literatura Moral, CANDAU, M. L.: «Los Libros de Avisos, fórmula de adoctrinamiento en la Europa Moderna», en Las mujeres y el honor en la Europa Moderna. Huelva, 2014, pp. 29-83

(C) Ediciones Universidad de Salamanca / ®@ Stud. his., H. ${ }^{a}$ mod., 38, n. 2 (2016), pp. 55-105 


\section{MARTA RUIZ SASTRE Y MARÍA LUISA CANDAU CHACÓN EL NOVIAZGO EN LA ESPAÑA MODERNA Y LA IMPORTANCIA DE LA «PALABRA». TRADICIÓN Y CONFLICTO}

incumplimiento de la citada y supuesta promesa, el valor de la palabra dada, los afectos que la fundaron y las manifestaciones de la pasión y su sexualidad son apartados que conectan la Historia de la familia y la cotidianeidad como tantos otros acercamientos en donde se cruzan todos los aspectos de la vida ${ }^{9}$. Amores y sexualidad, conducta moral y costumbres de la afectividad, expresiones que materializan el contexto cultural y social abrieron las puertas en nuestro país, terminando los ochenta, a valiosas aportaciones que engloban, lógicamente, el estudio de los tiempos previos al matrimonio en la Modernidad.

Entre ellas, resaltamos el camino trazado por James Casey en su Historia de la familia, esencialmente en el tratamiento de la "naturaleza de la pasión». Y valoramos los trabajos de las modernistas extremeñas Isabel Testón Núñez y Ángeles Hernández Bermejo ${ }^{10}$, a medio camino entre la historia social, cultural, de los afectos y en el último caso, de la Demografía Histórica; como los de Paula y Jorge Demerson para la Ibiza de la segunda mitad del XVIII, editado en $1993^{11}$. Por los mismos años, las investigaciones acerca de las relaciones prematrimoniales en ciertas áreas valencianas y gallegas de Pla Alberola y Dubert García ${ }^{12}$, en base a los registros parroquiales, demostraron las «coyunturas» de las costumbres, la importancia de la ilegitimidad, y las fluctuaciones del control eclesiástico y su efectividad.

9. A destacar los seminarios realizados desde la Universidad Complutense sobre la historia de la vida cotidiana, dirigidos por G. A. Franco Rubio, en su décima edición en abril de 2016, de temática bastante más amplia que la perseguida en este trabajo. Como ejemplo, Franco RuBio, G. A.: La vida cotidiana en tiempos de Carlos III. Madrid, 2001; Franco Rubio, G. A. y Pérez SAMPER, A. (Coord.): «Intimidad y sociabilidad en la España Moderna», monográfico en Revista de Historia Moderna. Anales de la Universidad de Alicante, 30, 2012; Franco Rubio, G. A.: «Fragmentos de cotidianeidad. Historias de lo cotidiano», Cuadernos de Historia Moderna, 2015, pp. 11-32. En otra dirección, Fargas Peñarrocha, M.: «Ni oírlos ni decirlos. Donde aguardan los secretos, una aproximación a la familia moderna», Cuadernos de Historia Moderna, 14, 2015, pp. 63-84; PeÑa DíaZ, M.: La vida cotidiana en el mundo hispánico (siglos XVI-XVIII). Madrid, 2012; Arias de SAAvedra, I. (Coord.): Vida cotidiana en la España de la Ilustración. Granada, 2012. Idem y López-Guadalupe, M. L.: Vida cotidiana en la Monarquía Hispánica. Tiempos y espacios. Granada, 2015.

10. Testón Núñez, I.: Amor, sexo y matrimonio. Badajoz, 1985. Hernández Bermejo, M. á.: La familia extremeña en los Tiempos Modernos. Badajoz, 1990.

11. Demerson, J. y Demerson, P.: Sexo, amor y matrimonio en Ibiza durante el reinado de Carlos III. Mallorca, El Tall, 1993.

12. Pla Alberola, P. J.: «Familia y matrimonio en la Valencia Moderna. Apuntes para su estudio», en Casey, J., Chacón, F., Gacto, E., Moll, I., Pla, P. J., Simón, A., Vincent, B.: La familia en la España mediterránea (Siglos XV-XIX). Barcelona, 1987, pp. 94-129. Dubert GarcíA, I.: «Los comportamientos sexuales premaritales en la sociedad gallega del Antiguo Régimen», Studia historica. Historia moderna, 9, 1991, pp. 117-142.

(C) Ediciones Universidad de Salamanca / ®@ Stud. his., H. ${ }^{a}$ mod., 38, n. 2 (2016), pp. 55-105 
MARTA RUIZ SASTRE Y MARÍA LUISA CANDAU CHACÓN

EL NOVIAZGO EN LA ESPAÑA MODERNA Y LA IMPORTANCIA DE LA «PALABRA». TRADICIÓN Y CONFLICTO

Pero en el tratamiento de los denominados pleitos matrimoniales (entre los que se incluyen las demandas «de palabra») fueron pioneras las incursiones de James Casey y Bernard Vincent y, más específicamente, las de María Juncal Campo Guinea y Francisco Javier Lorenzo Pinar ${ }^{13}$, historiadores que analizaron los inicios del matrimonio en diferentes áreas, desde ópticas y con fuentes parecidas. Si los registros parroquiales citados dieron pie al conocimiento de las relaciones prematrimoniales, por otra parte extendidas en la España Moderna, siendo fenómeno conocido sobre el que legislaron las Sinodales y se quejaron, regularmente, los visitadores generales en sus «resultas de visitas» ${ }^{14}$, los tribunales de justicia de entonces admitieron las demandas y las querellas analizadas para Granada por Casey, para Zamora por Lorenzo Pinar y para Pamplona por Campo Guinea, en un ámbito superior que englobaba otros conflictos contenidos bajo aquel término (matrimonios clandestinos, divorcios, vida maridable, nulidades eclesiásticas) ${ }^{15}$. Así, la Demografía Histórica, primero, y la Historia Judicial, después, se combinaban en el estudio del matrimonio, para demostrar la consideración, extendida, de ser el noviazgo bajo palabra una «institución»-aun entendida, por su esencia, transitoria- tan sólida a veces como el matrimonio, tan aceptada por el entorno y en su contexto como para considerar lógicas y asentadas las relaciones sexuales entre quienes poseían ya el compromiso. A fin de cuentas, lo que las demandas por incumplimiento de promesa de matrimonio corroboraban, sacando a la luz, por propio interés, la existencia de relaciones íntimas como prueba de la seguridad de su solemnidad futura, era la existencia de un consentimiento mutuo,

13. Casey, J., Vincent, B.: «Casa y familia en la Granada del Antiguo Régimen», en La familia en la España Mediterránea..., op. cit., pp. 172-212; CASEY, J.: «Le marriage clandestin en Andalousie a l'Époque moderne», en REDONDO, A.: Amours légitimes, amours ilégitimes en Espagne (XVI-XVIIe siècles). Paris, 1985, pp. 57-78. Traducido en Familia y sociedad en el Reino de Granada durante el Antiguo Régimen. Granada, 2008; Lorenzo Pinar, F. J.: «Conflictividad social en torno a la formación del matrimonio (Zamora y Toro en el siglo XvI)», Studia historica. Historia moderna, 13, 1995, pp. 131-154; Lorenzo PInAR, F. J.: Amores inciertos, amores frustrados (conflictividad y transgresiones matrimoniales en Zamora en el siglo XVII). Zamora, 1999; Campo GuineA, M. J.: Comportamientos matrimoniales en Navarra (siglos XVI-XVII). Pamplona, 1998.

14. Pla Alberola, P. J.: «Familia y matrimonio en la Valencia», cap. cit.; Candau Chacón, M. L.: Iglesia y sociedad en la Campiña sevillana. La vicaría de Écija (1627-1723). Sevilla, 1986; El clero rural de Sevilla en el siglo XVIII. Sevilla, Caja Rural, 1993.

15. Dejamos al margen -y no por su interés- los trabajos centrados en Cataluña debidos -por orden de aparición- a Antonio Gil Ambrona, Isabel Pérez, Ariadna Hernández y Roser Solé; más cercanamente Mariela Fargas. Su temática atiende, más bien, al fracaso conyugal, a los conflictos entre cónyuges y a la violencia doméstica.

(C) Ediciones Universidad de Salamanca / ®@ Stud. his., H. ${ }^{a}$ mod., 38, n. 2 (2016), pp. 55-105 


\section{MARTA RUIZ SASTRE Y MARÍA LUISA CANDAU CHACÓN EL NOVIAZGO EN LA ESPAÑA MODERNA Y LA IMPORTANCIA DE LA «PALABRA». TRADICIÓN Y CONFLICTO}

materializado en la realización de cópula, esencia por tanto de un «verdadero» matrimonio; ¿qué impedía entonces la intimidad?

Tales tratos «ilícitos» en cuanto que perseguidos por la ley -sobre todo eclesiástica- e ilícitos por contravenir el orden de las familias, si ellos pretendían formalizar matrimonios no deseados por algunas de las partes -entiéndase de los grupos- componían la esencia de la seducción. Y dejaron en muchas ocasiones huellas escritas en forma de billetes, letras de amor o cartas de cariño ${ }^{16}$, expresiones de afectividad que, al margen del valor otorgado por los historiadores a la correspondencia privada ${ }^{17}$, representaron en su día la prueba efectiva de la palabra dada. Considerando la óptica mayoritaria de las demandas, en donde primaban las provenientes de los defensores de las mujeres y de su honra, era de esperar que al hilo de la historia de género e historia de las mujeres surgiera, también, la

16. Casey, J.: Historia de la familia. Madrid, Espasa-Calpe, 1990; Usunáriz Garayoa, J. M.': María. Una visión de la América del XVIII. Correspondencia de emigrantes guipuzcoanos y navarros, Madrid, 1992; Navarro Bonilla, D.: Del corazón a la pluma. Archivos y papeles privados femeninos en la Edad Moderna. Salamanca, 2004; Baldellou Monclús, D.: «Cortejo, matrimonio y sentimientos en la España de la Ilustración a través de la correspondencia privada», Obradoiro de Historia Moderna, 23, 2014, pp. 217-248; UsunÁriz GARAYOA, J.: «Sentimientos e historia. La correspondencia amorosa en los siglos XVI-XVIII», en Castillo, A., SIERrA, V., (Eds.).: Cinco siglos de cartas. Historia y prácticas epistolares en las Épocas moderna y contemporánea. Huelva, 2014; Macías DomínguEZ, A. M.: «Emociones sobre el papel, cartas de cariño. Relaciones entre novios y desposados a través de sus cartas y billetes (Sevilla, siglo XVIII)», en CANDAu Chacón, M. L. (Ed.): Las mujeres y las emociones en Europa y América. Siglos XVII-XIX. Santander, 2016.

17. Отте, E.: Cartas privadas de emigrantes a Indias, 1540-1616. Sevilla, V Centenario, 1988; Macías Domínguez, I., Morales Padrón, F.: Cartas desde América, 1700-1800. Sevilla, V Centenario, 1991; Márquez Macías, R.: Historias de América: la emigración española en tinta y papel. Huelva, 1994. Testón NúNez, I., SÁnchez Rubio, R.: El hilo que une: las relaciones epistolares en el Viejo y Nuevo Mundo (siglos XVI-XVIII). Cáceres, 1999; Castillo GómEZ, A.: Entre la pluma y la pared: una historia social de la escritura en los Siglos de Oro. Madrid, 2006. Martínez Martínez, M. C.: Desde la otra orilla: cartas de Indias en el Archivo de la Real Chancillería de Valladolid (siglos XVI-XVIII). León, 2007; STANGL, W.: «Un cuarto de siglo con cartas privadas de emigrantes a Indias. Prácticas y perspectivas de ediciones de cartas transatlánticas en el Imperio español», Anuario de Estudios Americanos, 70, 2, 2013, pp. 703-736; MÁrQUeZ MACíAs, R.: «Cartas de amor y silencios: la correspondencia privada entre Buenos Aires y España en el siglo XVIII», Fundación, 7, 2004-2005, pp. 229-242; IDEM: «Cartas de mujeres emigrantes: nostalgia y recuerdos (siglos XVIII-Xix)», en Chivite de León, M. J., Hernández Pérez, M. B., Monzón Perdomo, M. E. (Coords.): Frontera y género: en los límites de la multidisciplinariedad. Madrid, 2011, pp. 171-185; IDEM: «El amor y el olvido en la correspondencia privada de los emigrantes en América», en Castillo Gómez, A., Sierra Blas, V. (Coords.): Cinco siglos de cartas. Op. cit., pp. 275-290; Márquez Macías, R, Candau Chacón, M. L.: «Las otras mujeres de América: las esclavas negras en tiempos de la Colonia. Un estudio a través de la correspondencia privada», en VAlero, S.: Negritud, estudios afrolatinoamericanos. Cartagena de Indias, 2014, pp. 213-235.

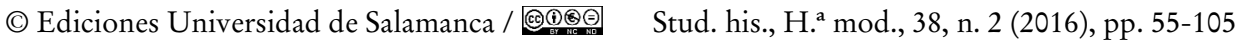


MARTA RUIZ SASTRE Y MARÍA LUISA CANDAU CHACÓN

EL NOVIAZGO EN LA ESPAÑA MODERNA Y LA IMPORTANCIA DE LA «PALABRA». TRADICIÓN Y CONFLICTO

historia de las burladas, seducidas y abandonadas (y sobre todo usadas) tras una promesa de matrimonio incumplida. Con diferentes ópticas -jurídicas, económicas y judiciales, sociales, morales o de género, o todas ellas- María Ángeles Ortego Agustín, Margarita Ortega, María Luisa Candau, María José de la Pascua ${ }^{18}$ analizaron, desde la Historia, en Madrid, Sevilla o Cádiz, la vertiente cotidiana de unas vidas que la literatura reflejaba como historias de ficción. Como en ciertos espacios gallegos, las migraciones de «la vergüenza» por Ofelia Rey ${ }^{19}$. Más recientemente los espacios aragoneses, castellanos y andaluces se han enriquecido con los trabajos de Daniel Baldellou, Margarita Torremocha, Marta Ruiz y Alonso Manuel Macías ${ }^{20}$, con diversas miradas, todas procedentes de las posibilidades

18. Ortego Agustín, M. A.: Familia y matrimonio en la España del siglo XviII. Ordenamiento jurídico y situación real de las mujeres a través de la documentación notarial. Tesis doctoral. Departamento de Historia Moderna. Universidad Complutense, Madrid, 1999. OrTEgA López, M.: «Protestas de las mujeres castellanas contra el orden patriarcal privado durante el siglo XVIII», Cuadernos de Historia Moderna, 19, 1997, pp. 67-89; IDEM: "Género e historia moderna: una revisión a sus contenidos», Contrastes. Revista de Historia, n. ${ }^{\circ} 11,1998-2000$, p. 27; IDEM: «Violencia familiar en el pueblo de Madrid durante el siglo XvIII», Cuadernos de Historia Moderna, 31, 2006, 7-37; CANDAu Chacón, M. L.: «Adulterio y malos tratos en la archidiócesis hispalense. Siglos XVII y XVIII", en Las mujeres en la Historia de Andalucía. Córdoba, Cajasur, 2002; IDEM: Un mundo perseguido: delito sexual y justicia eclesiástica en los Tiempos Modernos», en Furor et rabies, pp. 402-432; IDEM: «Mujer y deseo. La pasión contrariada de una viuda andaluza de fines del Seiscientos», en Espigado Tocino, G., Pascua Sánchez, M. ${ }^{a}$ J. de la, García-Doncel Hernández, M. R. (Coords.): Mujer y deseo: representaciones y prácticas de vida. Cádiz, Universidad de Cádiz, 2004, 405-418; IDEM: «El matrimonio clandestino en el siglo XVII: entre el amor, las conveniencias y el discurso tridentino", Estudios de historia de España, 8, 2006; 175-202; IDEM: «Entre lo permitido y lo ilícito: la vida afectiva en los Tiempos Modernos», Tiempos Modernos. Revista Electrónica de Historia Moderna, 6, 18, 2009 [En línea]; IDEM: «En torno al matrimonio: mujeres, conflictos, discursos», en PeÑa Díaz, Manuel (Ed.): La vida cotidiana en el mundo hispánico (siglos XVI-XVIII). Madrid, Abada Editores, 2012, pp. 97-118; PASCUA SÁNCHEZ, M. ${ }^{a}$ J. de la: Mujeres solas. Historias de amor y abandono en el mundo hispánico. Málaga, Diputación, 1998; IDEM: «Una aproximación a la historia de la familia como espacio de afectos y desafectos: el mundo hispánico del Setecientos», Chronica nova, 27, 2000, pp. 131-166; IDEM: «La recuperación de una memoria ausente: demandas judiciales y relatos de vida en la construcción de la historia de las mujeres», en Arenal. Revista de historia de mujeres, 12, 2, 2005, pp. 211-234; IDEM: «Regulación de los afectos y la cultura del amor en la sociedad hispana de la época Moderna», en Comercio y cultura en la Edad Moderna, op. cit.

19. De mujeres embarazadas, Rey Castelao, O.: «Las respuestas sociales a la pobreza femenina en la España de la Ilustración. Algunas notas», en LoBo DE Araujo M. M., Esteves, A. (Coords.): Marginalidade, pobreza e respostas sociais na Península Ibérica (séculos XVI-XX). Braga, CITCEM, 2011. En general, para los espacios gallegos, combinando las diferentes facetas de la vida de las mujeres, Rey Castelao, O.; Rial García, S.: Historia de las mujeres en Galicia, siglos XVI al XIX. Vigo, Nigratea, 2009.

20. Baldellou Monclús, D.: «Cortejo, matrimonio y sentimientos», art. cit.; Idem: «La posición de la mujer ante el matrimonio en las familias aragonesas del siglo XVIII», en SALAS

(C) Ediciones Universidad de Salamanca / ®@ Stud. his., H. ${ }^{a}$ mod., 38, n. 2 (2016), pp. 55-105 
MARTA RUIZ SASTRE Y MARÍA LUISA CANDAU CHACÓN

EL NOVIAZGO EN LA ESPAÑA MODERNA Y LA IMPORTANCIA DE LA «PALABRA». TRADICIÓN Y CONFLICTO

de las fuentes judiciales: pleitos matrimoniales que aportan cartas como pruebas de la promesa dada, que llevan a las mujeres aragonesas ante los tribunales, que revelan espacios de conflictos - previos y a causa del matrimonio- y que amplían la panorámica de investigación conectando los ámbitos institucionales con el mundo de las emociones. Utilizando el título de un monográfico citado, ratificando al matrimonio «en el corazón de la sociedad».

Así la documentación generada en este tipo de pleitos matrimoniales manifestará la reiteración del discurso tridentino, al menos hasta comienzos del xIx, años en los que la Pragmática de Carlos III de 1776, y posteriormente de Carlos IV en 1803, marcará el triunfo de la autoridad parental, como la decadencia de la imbatibilidad de los matrimonios por palabras de futuro. Hasta entonces, el concepto y la práctica del matrimonio católico -a pesar del Concilio- presentaba resquicios por los que colar el valor de la promesa: los verba de futuro. Pues si bien el decreto Tametsi había ratificado la solemnidad del sacramento mediante su publicidad, registro y celebración parroquial, in facie ecclesiae en presencia del sacerdote y testigos, a fin de evitar los clandestinos y los problemas consecuentes de conflictos inter-familiares, estableciendo, además, amonestaciones públicas precedentes, la realidad es que no desaparecieron totalmente los problemas tocantes a la relevancia de los esponsales. Quedaba claro que existían diferencias y que el verdadero matrimonio precisaba, salvo dispensas, de solemnidad, lo que equivalía a primar, en cierto modo, el valor del conocimiento público frente a la clandestinidad de las uniones que, por no ser permitidas por las familias, buscaban la privacidad del ocultamiento. Pero, a su vez, la defensa de la libertad de consentimiento y de su expresión -en palabras y con gestos- se ponía en peligro al exigirse su formulación pública. Añadiendo además que los verdaderos ministros y protagonistas del sacramento eran los

Auséns, J. A. (Coord.): Logros en femenino: mujer y cambio social en el valle del Ebro, siglos XVI-XVIII. Zaragoza, Prensas de la Universidad de Zaragoza, 2013, pp. 75-110; IDEM: «Un inesperado recurso. conflictividad social y moral para el acceso al matrimonio en la diócesis de Zaragoza, (s. XVIII), en Serrano MarTín, E. (Coord.): De la tierra al cielo. Lineas recientes de investigación en Historia moderna. Zaragoza, 2013. Torremocha Hernández, M., Drumond Braga, I. (Coords.): As mulheres perante os tribunais do Antigo Regime na Peninsula Iberica. Coimbra, Universidad de Coimbra, 2015; RuIz SASTRE, M.: Matrimonio, moral sexual y justicia eclesiástica en Andalucía Occidental: la Tierra Llande Huelva (1700-1750). Sevilla, Universidad de Sevilla, 2011; IDEm: Vidas unidas contra el discurso tridentino: el matrimonio clandestino en la Sevilla del Seiscientos", en Candau Chacón, M. L. (Ed.): Las mujeres y el honor en la Europa Moderna. Huelva, Universidad de Huelva, 2014, pp. 243-270; IDEm: Mujeres y conflictos... Tesis doctoral citada; Macías Domínguez, A. M.: El matrimonio, espacio de conflictos... Tesis doctoral citada; Ruiz Sastre, M., Macías Domínguez, A. M.: «La pareja deshecha. Pleitos matrimoniales en el Tribunal Arzobispal de Sevilla durante el Antiguo Régimen», Erebea. Revista de Humanidades y Ciencias Sociales, 2, 2012, pp. 291-320.

(C) Ediciones Universidad de Salamanca / ®@ Stud. his., H. ${ }^{a}$ mod., 38, n. 2 (2016), pp. 55-105 
MARTA RUIZ SASTRE Y MARÍA LUISA CANDAU CHACÓN

EL NOVIAZGO EN LA ESPAÑA MODERNA Y LA IMPORTANCIA DE LA «PALABRA». TRADICIÓN Y CONFLICTO

futuros cónyuges ¿cómo evitar la pervivencia de los matrimonios clandestinos, de los denominados presuntos, si llegado el caso, continuaban los enfrentamientos o los desajustes entre las elecciones de los jóvenes y las de sus padres? ¿Por qué no seguir realizando ceremonias semiprivadas -esponsales- con testigos de todo tipo como «adelanto» o compromiso de realizarse pública y solemnemente en tiempos propicios? ¿Y por qué no confiar en su cumplimiento?

La cuestión no radica únicamente en la lentitud de la maquinaria eclesiástica post-tridentina, en las fórmulas del disciplinamiento, en el adoctrinamiento que habría de comenzar por los curas y párrocos (Catecismo Romano, 1566) o en la propagación y aceptación de una doctrina matrimonial que tardaría en ser asimilada; la cuestión, en los países católicos procedía, pese a los intentos del Concilio, de pretender mantener a un mismo nivel libertad y solemnidad: dos principios no enfrentados necesariamente pero sí ocasional y probablemente, en tiempos en los que el matrimonio se entendía, sobre todo, desde los grupos medios hacia arriba, como conciertos de familias. La defensa del valor de la libertad de consentimiento como esencia del sacramento tenía sus inconvenientes, razón por la cual la institución habría de prever soluciones en situaciones de conflicto: a ello responderá el resguardo de las novias en depósito de familiares o su protección por el obispo, entre otras posibilidades.

La consecuencia de todo lo expresado es que en la Monarquía hispánica, como estado confesionalmente católico, desde la aprobación de los decretos del Concilio de Trento hasta las pragmáticas de los reyes Carlos III y Carlos IV, la realidad vivida apunta la continuidad de las promesas de matrimonio incumplidas; la consumación del trato carnal como consecuencia de dicha promesa; en no pocas ocasiones el retraso o directamente el incumplimiento de la palabra; la posterior demanda judicial requiriéndola de no existir mediadores o arbitrajes para un acuerdo que propiciase el desistimiento ${ }^{21}$; en definitiva la defensa -por parte de quienes se consideraron perjudicados por la no celebración del matrimonio públicode existir un verdadero compromiso desde el momento en el que los novios se otorgaron la palabra, bien comprometiéndose para el futuro, bien entregándose en el presente. La realidad, entonces, es que si bien Trento pretendió aclarar la diferencia entre esponsales y verdadero matrimonio, estableciendo que solo el expresado en palabras de presente lo era verdaderamente, y solo in facie ecclesiae, los compromisos continuaron, las relaciones se consumaron, los abandonos se produjeron y los matrimonios que muchos $-\mathrm{y}$ sobre todo muchas- creyeron

21. Sobre el desistimiento de esponsales según fuentes notariales, Ortego Agustín, M. A., op. cit.

(C) Ediciones Universidad de Salamanca / ®@ Stud. his., H. ${ }^{a}$ mod., 38, n. 2 (2016), pp. 55-105 
MARTA RUIZ SASTRE Y MARÍA LUISA CANDAU CHACÓN

EL NOVIAZGO EN LA ESPAÑA MODERNA Y LA IMPORTANCIA DE LA «PALABRA». TRADICIÓN Y CONFLICTO

contraer (matrimonios presuntos) se «pleitearon». La realidad es, también, que los clandestinos decayeron en la segunda mitad del siglo XVII; en «contraposición» las promesas de matrimonio persistieron y su validez siguió utilizando un discurso a veces contradictorio: porque el valor de la palabra otorgada en un tiempo previo al verdadero matrimonio público y solemne, de existir la unión carnal, y en función de la igualdad social de los «prometidos» se respetaba por el tribunal de la Iglesia. ¿Dónde quedaba entonces la misión de un decreto -el Tametsi-que había luchado por la exclusiva validez de los matrimonios celebrados solemne y públicamente, ante testigos, sacerdote y en la iglesia? La existencia de las fuentes judiciales que analizamos aquí prueba la dificultad de combinar las tradiciones asentadas -y en ellas la interpretación del honor sexual-y la normativa conciliar.

\section{Que no faltaría a SU PALAbRa AUNQUe LE ECHASEN A UNA GALERA. LA PALAbRa EN FORMAS: EL PROCESO}

Ana Gómez, vecina de la localidad sevillana de Fuentes, al ser interrogada por el tribunal eclesiástico hispalense sobre la promesa de matrimonio supuestamente desatendida por Alonso Lozano, aseguraba que el susodicho le había garantizado que primero le faltaría la salvación que se dejase de casar con su parte, pues no faltaría a su palabra aunque le echasen a una galera ${ }^{22}$. Los enunciados en su día pronunciados por el después acusado permiten entrever su doble consideración de pecado y delito, puesto que hacen referencia a las penas espirituales y terrenales que podían derivar del abandono de una promesa. Y es que el desistimiento de la «palabra» afectó, a un tiempo, al ámbito civil y al religioso. Al Estado, porque la unión conyugal constituía la base del ordenamiento social; y a la Iglesia porque comprometía los términos de realización de un sacramento, el del matrimonio ${ }^{23}$. Se trataba de un asunto de fuero mixto, pudiendo las partes pleiteantes escoger uno u otro tribunal -secular o eclesiástico- para dar solución al problema. No obstante, el volumen de pleitos seguidos ante la justicia eclesiástica prueba el papel prioritario de la Iglesia en este tipo de disputas ${ }^{24}$. Desde el momento en que se cuenta con una normativa legal más precisa (Concilio de Trento), su transgresión resulta más evidente, provocando un incremento lento pero progresivo de tales

22. Archivo General del Arzobispado de Sevilla [en adelante AGAS], Sección Justicia, Serie matrimoniales, leg. 63, exp. 1, 1680.

23. Candau Chacón, M. L.: «Honras perdidas por conflictos de amor: el incumplimiento de las palabras de matrimonio en la Sevilla Moderna. Un estudio cualitativo", Fundación, 7, 2004-2005, p. 183.

24. Candau Chacón, M. L.: «Entre lo permitido y lo ilícito». Artículo citado.

(C) Ediciones Universidad de Salamanca / ®@ Stud. his., H. ${ }^{a}$ mod., 38, n. 2 (2016), pp. 55-105 
MARTA RUIZ SASTRE Y MARÍA LUISA CANDAU CHACÓN

EL NOVIAZGO EN LA ESPAÑA MODERNA Y LA IMPORTANCIA DE LA «PALABRA». TRADICIÓN Y CONFLICTO

causas $^{25}$. En líneas generales el cambio comienza a percibirse en torno a 1580 , en relación con los intentos de reconducir la concepción popular de la promesa y la criminalización de costumbres previamente reconocidas como legítimas, así como con la intensificación del control ejercido por la Iglesia sobre todos los asuntos tocantes al séptimo sacramento ${ }^{26}$.

Respecto a la dinámica de los procesos reproducimos el esquema definido por Francisco Javier Lorenzo Pinar, dado que el funcionamiento de la justicia fue similar en todos los tribunales de titularidad eclesiástica ${ }^{27}$. Para empezar, el demandante -O su representante legal- exponía su caso ante el Obispo o Provisor de la Diócesis. En el acta de acusación, redactada con la ayuda de un procurador, se recopilaban los datos considerados más relevantes para sustentar y dar credibilidad a la querella. La reconstrucción de los hechos solía seguir una tipología argumentativa bastante común y repetitiva, ajustada a aquello que las autoridades habían delimitado previamente -tanto mediante la escritura de la norma, como durante el desempeño práctico de sus labores de control y arbitraje- como susceptible de ser atendido en sede judicial ${ }^{28}$. Expuesta la situación ante la justicia, y existiendo pruebas irrefutables, se ordenaba encarcelar al acusado para evitar su huida, concediéndosele un plazo, bien

25. Tendencia constatada para Zamora y Toro, la Diócesis de Pamplona, y el Arzobispado sevillano. Lorenzo Pinar, F. J.: «Conflictividad social»; CAmpo Guinea, M. J.: Comportamientos matrimoniales en Navarra; DUbert García, I.: «Los comportamientos sexuales»; CANDAU Chacón, M. L.: «Entre lo permitido y lo ilícito...», op. cit.; Macías Domínguez, A. M.: El matrimonio, espacio de conflictos. Op. cit.; RuIZ SASTRE, M.: Mujeres y conflictos en los matrimonios de Andalucía occidental. El Arzobispado de Sevilla durante el siglo XVII. Tesis doctoral, Departamento de Historia II y Geografía, Facultad de Humanidades, Universidad de Huelva, 2016. Más allá del ámbito hispano, el estudio comparativo realizado por Giovanni Ciapelli prueba la misma tendencia alcista en las ciudades italianas de Verona, Nápoles y Feltre. Ciappelli, G.: «I procesi matrimoniali: quadro di raccordo dei risultati della schedatura», en SEIDEL MENCHI, S. y Quaglioni, D. (dirs.): I tribunali del matrimonio (secoli XV-XVIII). Bolonia, Il Mulino, 2006, pp. 67-100. Para los casos concretos de Nápoles y Feltre puede consultarse también PARENTE, U. y Scaramella, P.: «I processi matrimoniali napoletani (secoli XVI-XVII)», en SeIdel MenchI, S. y Quaglioni, D. (dirs.): I tribunali del matrimonio..., op. cit., pp. 163-188 y POIAN, M.: «I processi matrimoniali dell'Archivio Vescovile di Feltre (secoli XVI-XVIII)», en SEIdel Menchi, S. y Quaglioni, D. (dirs.): I tribunali del matrimonio..., op. cit., pp. 141-161.

26. Luperini, S.: «La promessa sotto accusa (Pisa 1584)», en Seidel Menchi, S. y Quaglioni, D. (dirs.): Matrimoni in dubbio. Unione controverse e nozze clandestine in Italia dal XIV al XVIII secolo. Bolonia, Il Mulino, 2001, pp. 363-394.

27. Lorenzo Pinar, F. J.: «Conflictividad social...», op. cit., pp. 131-154.

28. María Luisa Candau habla de una «institucionalización» de las querellas, pues todas siguen un mismo patrón configurado para salvar el honor de los demandantes y de sus familias. Candau Chacón, M. L.: «Honras perdidas por conflictos de amor...», op. cit., 182. Por su parte, Arlette Farge hace mención a una «alteración deliberada de la realidad». FARGE, A.: La vie fragile. Violence, pouvoirs et solidarités à Paris au XVIII siècle. París, Points, 1986.

(C) Ediciones Universidad de Salamanca / ®@ Stud. his., H. ${ }^{a}$ mod., 38, n. 2 (2016), pp. 55-105 


\section{MARTA RUIZ SASTRE Y MARÍA LUISA CANDAU CHACÓN EL NOVIAZGO EN LA ESPAÑA MODERNA Y LA IMPORTANCIA DE LA «PALABRA». TRADICIÓN Y CONFLICTO}

para casarse, bien para defender su causa. Para el caso de las mujeres, querellantes o acusadas, los Vicarios solían optar por el depósito en algún monasterio o casa de gente principal bajo la prohibición de comunicarse con nadie que pudiese alterar su voluntad, a fin de garantizar su seguridad y de obtener declaraciones realizadas en condiciones de plena libertad ${ }^{29}$. Finalmente, tomadas las confesiones de ambas partes, examinados los testigos del plenario y realizadas las alegaciones pertinentes por parte de los procuradores, el tribunal emitía su sentencia.

En el origen del recurso a la justicia y de la puesta en marcha de toda su maquinaria, nuestro objeto de estudio: el incumplimiento de la «palabra» ¿Qué causas explican estos «olvidos»? ¿Cuáles fueron las situaciones que animaron a los damnificados a hacer uso de los tribunales para reclamar aquello que les era debido? Los motivos que suelen esconderse detrás de las faltas a la promesa son de naturaleza variada ${ }^{30}$. No obstante, tres fueron las razones más recurrentes. A saber: la intención de contraer otro matrimonio, la clara oposición por parte de allegados hacia determinados enlaces, y las largas dilaciones y esperas -por diferentes razones, como el parentesco-, sobre todo cuando se había producido cópula entre la pareja. En el primero de los supuestos, el problema surgía por la existencia de dos o más promesas simultáneas, especialmente al hacerse pública la intención de concretar in facie ecclesiae una de ellas. Por regla general, el reparto de papeles en estos casos reproduciría un mismo patrón: sería el hombre el protagonista del abandono. Las proporciones numéricas y su perdurabilidad confirman dicha afirmación. En el Arzobispado de Sevilla, durante el siglo xviI, más del 80\% de las demandas interpuestas por mujeres -o por sus parientes- respondía a este móvil, no resultando extraño encontrar pleitos en los que varias féminas intervinieron para disputarse un mismo cónyuge $\mathrm{e}^{31}$. Y entre 1707 y 1762, los pleitos seguidos

29. Al respecto dos matizaciones: primero, en ocasiones serían las propias jóvenes quienes, sin mediar intervención de la justicia, escaparan procurando refugio; y segundo, a pesar de las cautelas tomadas a instancia judicial, siempre hubo quien se las ingenió para entrar en contacto con ellas durante el periodo de aislamiento con la intención de influir en sus testimonios y acciones.

30. Sirvan a modo de ejemplo el fracaso en las expectativas de una dote, la sospecha acerca de la honestidad de la mujer, la diferente procedencia geográfica, las posibilidades de mejora ofrecidas por la carrera profesional, los temores al abandono de la pareja una vez contraído el matrimonio, la no obtención de dispensa en los casos de vínculos consanguíneos, o, incluso, la falta de virginidad o la frialdad de la mujer fundamentada a través de relaciones prematrimoniales. Sobre este último particular, posible en zonas de mayor permisividad sexual, TeSTÓN NúÑEZ, I.: Amor, op. cit., p. 31. También Lorenzo Pinar, F. J.: Amores inciertos, op. cit., pp. 59-60.

31. La secuencia de acontecimientos es siempre la misma: la parte presuntamente defraudada acude al párroco para dar noticia de su situación tratando de impedir la celebración del matrimonio mientras transcurre el periodo de las amonestaciones; seguidamente interpone

(C) Ediciones Universidad de Salamanca / ®@ Stud. his., H. ${ }^{a}$ mod., 38, n. 2 (2016), pp. 55-105 


\section{MARTA RUIZ SASTRE Y MARÍA LUISA CANDAU CHACÓN EL NOVIAZGO EN LA ESPAÑA MODERNA Y LA IMPORTANCIA DE LA «PALABRA». TRADICIÓN Y CONFLICTO}

ante el oficio II del mismo arzobispado ratifican una apabullante superioridad: el $97 \%$ de las demandas defendían los derechos de las mujeres ${ }^{32}$. En los espacios gallegos, la tendencia a recurrir a la justicia reclamando una promesa cuando el hombre procura contraer un matrimonio alternativo perdurará aún a principios del siglo $\mathrm{XIX}^{33}$.

El segundo de los grupos mayoritarios de contenciosos lo conforman las demandas que llegan bajo la forma de suspensión del estado de libre elección de alguno de los contrayentes por parte de sus deudos o parientes. Causas de este tipo aparecen por todo el mundo católico. Incluso en fechas previas al Concilio de Trento. Lucía Ferrante, por ejemplo, estudia el caso de María de Reggio y Camino Buganelli, feligreses del obispado de Bolonia, que hacia 1549 defendieron su voluntad de contraer matrimonio pese a la presión ejercida por sus familiares ${ }^{34}$. Con relativa frecuencia los progenitores se mostraron disconformes con las decisiones tomadas por sus hijos en materia matrimonial, e intervinieron

demanda formal ante el tribunal contra su supuesto prometido argumentando haber recibido palabra de casamiento con anterioridad a la fecha en que lo hizo a su rival. Ruiz SASTRE, M.: Mujeres y conflictos... op. cit., 311 y ss.

32. Cuantitativamente, para tales años (1707-1762), la actividad del oficio segundo del tribunal arzobispal alcanzó un total de 2.599 pleitos matrimoniales; a ellos habría que añadir cuatro legajos de matrimonios secretos y ochenta y cuatro ramos de autos relajados y no seguidos. Los primeros -matrimonios secretos- hacían referencia a los que, con permiso arzobispal y por causas diversas (duelos, escándalo, ausencia de consentimiento paterno) se realizaron sin las preceptivas amonestaciones o bien con un número menor; no han de confundirse entonces con los ya casi desaparecidos matrimonios clandestinos; los segundos apuntaban los pleitos desistidos, bien por acuerdos entre las partes -que no excluían negociaciones- bien por no ser admitidos ni consolidados como querella. Los citados más de 2.600 pleitos matrimoniales (considerando las particularidades mencionadas) constituyeron una gran parte de la actividad de los tribunales. La totalidad de los pleitos (matrimoniales, autos ejecutivos y causas criminales) que pasaron ante el oficio segundo (1707-1762) rondaban los 10.000. De ellos -de los mencionados más de 2.600 -, prácticamente la mitad respondía a demandas por incumplimiento de palabra de casamiento, alcanzando un total de 1.397. Suponiendo una actividad semejante en cuanto a pleitos matrimoniales para el oficio primero, podríamos como máximo, duplicar la cifra. Una proporción semejante a la obtenida para tiempos parecidos en otras áreas y que refleja la relevancia de este tipo de procesos, de forma que uno de cada dos pleitos matrimoniales se producía, precisamente, por los conflictos en torno a su realización solemne. CANDAU CHACÓN, M. L.: «Honras perdidas por conflictos de amor...», art. cit. Sobre el funcionamiento de los tribunales eclesiásticos sevillanos y la distribución de los oficios I y II, PINEDA Alfonso, J. A.: El gobierno del tribunal arzobispal de Sevilla en el siglo XVII. Tesis doctoral inédita. Departamento de Historia Moderna. Defendida en diciembre de 2015.

33. Dubert García, I.: «Église, monarchie, mariage et contrôle social dans la Galice rurale XviIIe et XIXe siècles», Annales de démographie historique, 2, 2009, pp. 101-121.

34. Ferrante, L.: «Gli sposi contesi. Una vicenda bolognese di metà Cinquecento», en Seidel Menchi, S. y Quaglioni, D. (dirs.): Matrimoni in dubbio..., op. cit., pp. 329-362.

(C) Ediciones Universidad de Salamanca / ®@ Stud. his., H. ${ }^{a}$ mod., 38, n. 2 (2016), pp. 55-105 
MARTA RUIZ SASTRE Y MARÍA LUISA CANDAU CHACÓN

EL NOVIAZGO EN LA ESPAÑA MODERNA Y LA IMPORTANCIA DE LA «PALABRA». TRADICIÓN Y CONFLICTO

al efecto presionando para hacerles desistir de sus intenciones. Entre las causas que lo propiciaron sobresalen la diferente «calidad» de los novios, la existencia de vínculos de consanguinidad o afinidad, una reputación cuestionable de la mujer, o el origen incierto del contrayente. Caso aparte lo constituía el de las muchachas cuyos padres -llegado el momento- carecían de medios suficientes para dotarlas, decidiendo su ingreso en un convento, opción menos gravosa para la hacienda familiar. Sea cual fuere el motivo elegido para estorbar o impedir el enlace, el hecho de que se contabilice un considerable número de procesos en los que se alegue intromisión de parientes como causa del incumplimiento de la palabra habla bien a las claras de las dificultades de la aplicación del principio de libre consentimiento. Independientemente de su resolución. $\mathrm{O}$ al menos no plenamente, ya que debe recordarse que los litigios contenidos en los archivos judiciales representan una ínfima parte del cómputo global de la sociedad de los Tiempos Modernos. Cabría preguntarse qué sucedió en el resto -la mayoría- de las historias personales y familiares.

Finalmente localizamos las denuncias inferidas por la negativa de una de las partes a contraer matrimonio de presente, tras las reiteradas demandas de la otra. Son casos en los que la parte acusada -habitualmente- esgrime razones de naturaleza económica para justificar la demora. Pretexto mayoritario al que sumar el deber de cuidar de los padres, el temor a posibles represalias de familiares cercanos, la falta de salud, la marcha hacia territorios lejanos o el cumplimiento de condenas judiciales pendientes. Argumentos todos con los que, en definitiva, no se hacía sino alargar el plazo de cumplimiento de la palabra dada. El patrón de conducta se convierte en tópico: el varón frecuenta a la mujer, consigue sus favores en un intercambio de virtud por palabra de casamiento para, posteriormente, abandonarla. Tales fueron sus argumentos: la credulidad y, consecuentemente, la pérdida de la virtud.

Con independencia del móvil del abandono, demostrar que realmente había existido intercambio de palabras de matrimonio se convertirá en objetivo prioritario de quienes reclamaron la unión legítima por palabras de presente. Aportar datos precisos sobre el tiempo, lugar y visibilidad del momento en el que había tenido lugar el compromiso era prioritario. Por ello, en caso de que la información aportada no satisficiese las exigencias del tribunal, se procedía al interrogatorio de la parte demandante acerca de las circunstancias en que supuestamente se había producido el intercambio de la palabra. De este modo, mediante preguntas acerca de la identidad de las personas presentes en el acto, del lugar, vestimentas, fecha y hora del día de autos, se procuraba comprobar la veracidad del acto de la promesa. Y recurriendo a estas pesquisas, se podía reconstruir el escenario, las circunstancias y los términos en que se produjeron los esponsales. Sirva de ejemplo el siguiente 
MARTA RUIZ SASTRE Y MARÍA LUISA CANDAU CHACÓN

EL NOVIAZGO EN LA ESPAÑA MODERNA Y LA IMPORTANCIA DE LA «PALABRA». TRADICIÓN Y CONFLICTO

repertorio de cuestiones contenidas en uno de los expedientes del Archivo General del Arzobispado de Sevilla:

cuánto tiempo ha las palabras de casamiento, en qué año fueron y en qué ocasión, y si era de invierno o de verano, de noche o de día, por la tarde o por la mañana, en qué sitio, parte o lugar, si llovía o hacía sol, o si fue en el patio o en algún aposento diga cuál, y a qué hora, cuántas veces dio dicha palabra, y de qué manera, cómo se la dijo y dio, y qué personas estaban presentes ${ }^{35}$.

El intercambio de alianzas u otras prendas entre los desposados - «testigos inertes», en palabras de Francisco Javier Lorenzo Pinar ${ }^{36}-$, la presencia de clérigos o la aportación de cartas o billetes de contenido amoroso, serían otros recursos empleados por los demandantes para certificar la existencia de la "palabra». Sortijas, imágenes o escritos íntimos -innecesarios en la realización de los esponsales- resultarían sin embargo de ayuda en el Seiscientos, ya que a partir del siglo xviII todos estos elementos comenzarán a perder valor probatorio frente a nuevas prácticas de «blindaje ${ }^{37}$ de esponsales. El protocolo y la parafernalia anterior dejarían de ser suficientes, exigiéndose, desde mediados del Setecientos en adelante, la formalización mediante escritura pública del acuerdo contraído entre las partes ${ }^{38}$. El fin: probar la aquiescencia de los desposados con el matrimonio en cuestión, al tiempo que evitar malos entendidos, cambios de opinión de última hora y subsiguientes conflictos por el incumplimiento de la palabra.

Sin duda, la prueba más valorada sería la existencia de testigos, incluso en las historias que narraban promesas realizadas en la intimidad; pero aun en estos casos se reclamaba la presencia de algún vecino o conocido de la pareja que supiera de tales relaciones. La causa no era otra que asegurar la existencia de sujetos que

35. AGAS, Sección Justicia, Serie matrimoniales, leg. 63, exp. 4, 1682.

36. Lorenzo Pinar, F. J.: "Conflictividad social...», op. cit., p. 147.

37. Termino empleado en La Rocca, C.: Tra moglie e marito. Matrimoni e separazioni a Livorno nel Settecento. Bolonia, Il Mulino, 2009, pp. 80-81. En su estudio sobre la ciudad de Livorno describe la costumbre de realizar una «scritta di sponsali», siendo habitual que los contrayentes o sus familias leyeran o hicieran leer el escrito, el cual sería seguidamente firmado por las partes delante de testigos.

38. Casi todas las escrituras contienen los mismos asuntos. En primer lugar aparece el nombre de los futuros esposos y de sus padres o tutores, quienes consienten celebrar el matrimonio in facie ecclesiae. Suele seguir una referencia a las consecuencias penales que derivan del incumplimiento de la promesa. Y finaliza con los términos relativos a la dote (cuantía, quién se hace cargo del pago, momento en que será entregada, y promesa de que será devuelta en los casos previstos por los estatutos), si bien Daniela Lombardi asegura que este aspecto económico no necesariamente era contemplado siempre. Lombardi, D.: Matrimoni di Antico Regime, Bolonia, Il Mulino, 2001. 
MARTA RUIZ SASTRE Y MARÍA LUISA CANDAU CHACÓN

EL NOVIAZGO EN LA ESPAÑA MODERNA Y LA IMPORTANCIA DE LA «PALABRA». TRADICIÓN Y CONFLICTO

pudieran confirmar -en caso de que fuera necesario- la formalización del compromiso. Ahora bien, el devenir del pleito, la obtención -o no- de un fallo favorable del tribunal, dependería del número y fiabilidad de dichos testigos. Según los casos, la existencia de un único testigo podía resultar determinante, mientras que, por el contrario, varias declaraciones de personas sin credibilidad podían obrar a favor de la parte acusada. Por regla general, sexo (femenino), edad y minusvalía restaban valor a los testimonios ofrecidos.

Cuando no se podía aportar testigo alguno, o resultaban vagas e imprecisas las respuestas a los interrogatorios, la parte demandante procuraba demostrar el vínculo haciendo referencia a la intimidad alcanzada en el trato a raíz de la promesa. Alegaban retozos, conversaciones públicas y visitas frecuentes. Conversar, compartir «mesa y mantel», intercambiar regalos, constituían algunos de los comportamientos fácilmente distinguibles en la vida de los desposados. También las riñas y peleas como actitudes propias de quienes habían de convertirse en marido y mujer. Y es que la promesa legitimaba a los ojos de la sociedad el cortejo oficial a la joven, así como la asidua frecuentación de la pareja sin menoscabo de la honra, incluyendo, según dijimos, pernoctaciones del varón. Al respecto se presentarán ante los tribunales los testimonios de convecinos que, ignorando su condición de prometidos, reconvinieron a la pareja cuando públicamente se otorgaban muestras excesivas de efusividad; al igual que el testimonio de aquellos otros que, conocedores de su compromiso, consintieron y contemplaron con regocijo esas mismas manifestaciones de afecto sintiendo próximo el futuro enlace, prueba del significado que tenía la promesa para muchos. Tales conductas se mantuvieron de forma similar a lo largo de la Modernidad, cambiando únicamente con el tiempo la manera o la frecuencia con que fueron presentadas ante los tribunales ${ }^{39}$. Realidad que, pensamos, habría estado relacionada con el progresivo calado de la norma tridentina en la sociedad, aunque -insistimos- esta asimilación de la doctrina dictada por el Concilio no se habría reflejado tanto en las conductas como en las estrategias judiciales.

El grado de mayor intimidad -el de las relaciones sexuales- también aparece recogido en los litigios. Se trataba de un recurso empleado fundamentalmente por las mujeres, principales querellantes y protagonistas indiscutibles de la mayoría de los pleitos seguidos por incumplimiento de esponsales. A fin de cuentas, ellas constituían la parte más perjudicada por la publicidad de aquellos actos a los que habían accedido creyendo en los proyectos de vida futura ofrecidos por quienes

39. Al respecto Ruiz SAstre, M.: Mujeres y conflictos..., op. cit., pp. 308 y ss.

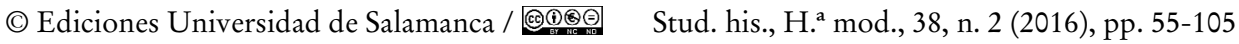


MARTA RUIZ SASTRE Y MARÍA LUISA CANDAU CHACÓN

EL NOVIAZGO EN LA ESPAÑA MODERNA Y LA IMPORTANCIA DE LA «PALABRA». TRADICIÓN Y CONFLICTO

ahora -decían- las abandonaban ${ }^{40}$. Su discurso en sede judicial es unánime: jamás hubieran consentido mantener relaciones íntimas de haber conocido las verdaderas intenciones del novio. A ellas, por su honor, especialmente en los casos en los que se había hecho pública la deshonra, no les quedaba más remedio que pleitear en los tribunales; una resolución que, dependiendo de la zona geográfica a la que nos refiramos, afrontarán en solitario o con el respaldo de deudos y parientes. En el caso de la capital hispalense, por ejemplo, sólo una ínfima parte de los pleitos seguidos ante la justicia eclesiástica por desistimiento de palabra de casamiento durante el siglo XVII sería incoada por iniciativa paterna ${ }^{41}$. Tampoco en el XVIII. Por el contrario, los casos analizados por Daniel Baldellou para la diócesis de Barbastro revelan un $40 \%$ de demandas realizadas por parte de los padres de las jóvenes defraudadas ${ }^{42}$. La explicación a estas diferencias habría que buscarla en las costumbres de las gentes de cada territorio. En el segundo de los casos, como señala el propio autor, predominaba casi de forma exclusiva la familia troncal, según la cual, la iniciativa de cualquier acción legal correspondía al sujeto que actuaba en representación del grupo. La razón de la plena autoridad paterna no era otra que la propia supervivencia. Según Baldellou, la flexibilidad testamentaria aragonesa llevaba a permitir el nombramiento de un heredero único para evitar la parcelación de las posesiones; desigual reparto que obligaba irremediablemente a los hijos desheredados a vivir a costa del hermano beneficiario, de quien, en contraprestación por la relación de cierta servidumbre y sumisión, esperaban tratase para ellos un matrimonio propicio y acorde a las posibilidades económicas de la familia ${ }^{43}$. En contraposición, en todo el Arzobispado sevillano imperaba el sistema hereditario castellano. Según este régimen de transmisión patrimonial, sustentado en las Leyes de Toro (1505) e inspirado en el Fuero Real y Las Parti-

40. Así lo constatan los resultados obtenidos para el Arzobispado de Sevilla o para el caso navarro. Macías Domínguez, A. M.: El matrimonio, espacio de conflictos..., op. cit.; RuIz SASTRE, M.: Mujeres y conflictos..., op. cit.; CAMPO GuINEA, M. J.: «Los procesos por causa matrimonial ante el Tribunal Eclesiástico de Pamplona. Siglos XVI y XvII», Príncipe de Viana, año n. ${ }^{\circ} 55$, n. $^{\circ}$ 202, 1994, pp. 377-389. Otros estudios, sin embargo, como el realizado por Francisco Javier Lorenzo Pinar, han obtenido como resultado un mayor porcentaje de hombres pleiteantes $(55 \%)$, a excepción de las situaciones en las que se acudía a la justicia ante la pretensión del prometido de contraer matrimonio con otra persona. En tales circunstancias fue la mujer (en dos de cada tres casos) la que estuvo dispuesta a interferir en el enlace para hacer cumplir la supuesta palabra. Lorenzo Pinar, F. J.: «Conflictividad social...», op. cit., pp. 131-154.

41. Ruiz Sastre, M.: Mujeres y conflictos..., op. cit., pp. 317-318.

42. Baldellou Monclús, D.: «La posición de la mujer ante el matrimonio en las familias aragonesas del siglo XVIII», cap. cit., pp. 88-89.

43. Esto junto al deber moral de mantener a los hermanos menos favorecidos constituye lo que ha sido denominado «ética del reparto». Ibidem.

(C) Ediciones Universidad de Salamanca / ®@ Stud. his., H. ${ }^{a}$ mod., 38, n. 2 (2016), pp. 55-105 
MARTA RUIZ SASTRE Y MARÍA LUISA CANDAU CHACÓN

EL NOVIAZGO EN LA ESPAÑA MODERNA Y LA IMPORTANCIA DE LA «PALABRA». TRADICIÓN Y CONFLICTO

das, la herencia debía ser distribuida de forma relativamente equitativa entre los descendientes ${ }^{44}$. Al primar la fórmula distributiva, las estrategias familiares fueron diferentes. No existía esa dependencia (en forma de sumisión y servidumbre a cambio de amparo) del miembro de la familia privilegiado por la primogenitura, sino que, al participar todos en la medida correspondiente de las transmisiones patrimoniales, se propiciaría una mayor independencia de cada uno de ellos, lo que para el caso de las mujeres se traducía en cierta autonomía de decisión. Ellas, por tanto, se sentirían más libres para actuar según su propio criterio sin tener que respetar de manera rigurosa la opinión de sus tutores.

Solas o acompañadas, la nada desdeñable cifra de mujeres que recurrieron al pleito para defenderse, al ver vulnerados sus derechos, demuestra que en cuestiones de matrimonio la mujer no funcionaba como un elemento pasivo, sino que tenía sus propios objetivos y estrategias para alcanzarlos. Sabían el discurso a emplear y las armas a utilizar. Con un fin: reanudar la relación y lograr la seguridad del matrimonio en una sociedad donde la soltería se hallaba minusvalorada.

Pese a todo, las posibilidades de éxito no estaban aseguradas. Ellas conocían sus límites; también sus familias al ampararlas ante los tribunales y negociar una compensación económica ofreciendo a cambio la cancelación del litigio. Ante matrimonios imposibles -especialmente por diferencias sociales- las estrategias cambiaban: perseguían entonces satisfacción material -por el abandono- y reparación moral.

Por el mismo protagonismo femenino, los jóvenes demandados se perfilaban como seres perversos y desalmados ${ }^{45}$. Hombres sin escrúpulos que habrían seducido, burlado y «gozado» a mujeres bajo falsas promesas de matrimonio ${ }^{46}$.

44. La herencia debía ser dividida en cinco partes iguales, cuatro de las cuales forzosamente debían transmitirse a los hijos. De esos cuatro quintos, el testador tenía que repartir dos tercios en partes iguales, pudiendo mejorar con el tercio restante a los sucesores que libremente determinara. La quinta parte pendiente, no computada como legítima, quedaba a su libre disposición, pudiendo acumularse al tercio de mejora.

45. Candau Chacón, M. L.: «Otras miradas: el discurso masculino ante el incumplimiento de las promesas de matrimonio. Sevilla, siglos xvir y xviI», en Fuente Pérez, M. J.; López Serrano, A. y Palanco, F. (Coords.): Temas de historia de España: estudios en homenaje al profesor don Antonio Domínguez Ortiz. Madrid, Asociación Española del Profesorado de Historia y Geografía, 2005, p. 226.

46. En los territorios de la Monarquía Hispánica y de la Península italiana las promesas desatendidas fueron vistas como delitos típicamente masculinos. Por el contrario, en las áreas inglesa, alemana y suiza las mujeres fueron señaladas como las principales culpables de las relaciones prematrimoniales. HACKE, D.: «La promessa disattesa: il caso di Perina Gabrieli (Venezia 1620)», en Seidel Menchi, S. y Quaglioni, D. (Dirs.): Matrimoni in dubbio..., op. cit., p. 413; Seidel Menchi, S.: «I processo matrimoniali come fonte storica», en Seidel MenCHI, S. y

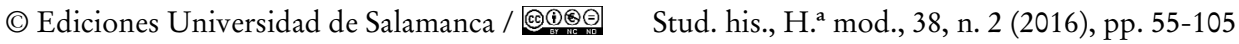


MARTA RUIZ SASTRE Y MARÍA LUISA CANDAU CHACÓN EL NOVIAZGO EN LA ESPAÑA MODERNA Y LA IMPORTANCIA DE LA «PALABRA». TRADICIÓN Y CONFLICTO

Hombres, a fin de cuentas, conocedores de las ventajas brindadas por la sociedad patriarcal, y de las artes a seguir para dar satisfacción a sus deseos. Sin embargo, no podemos dejar de considerar la otra cara de la deshonra y su pretendida reparación: el desarrollo de la picaresca femenina y el empleo de estas historias para obtener resarcimientos materiales en casos en los que realmente no había mediado nunca palabra de casamiento. Debemos poner en duda, cuanto menos, el que todas las demandas presentadas ante el tribunal respondiesen a verdaderas promesas de matrimonio. La urgencia por tomar estado o conseguir algún alivio económico en tiempos difíciles empujaría a muchas mujeres a hacer uso de todo tipo de artimañas para conseguir sus fines -por lo general, más materiales que morales- denunciando a personas con las que apenas habrían mantenido relación. El litigio, así, será usado por la mujer necesitada como instrumento jurídico de utilidad y del que disponer para tratar de obtener beneficios económicos. Por tanto, en tales casos, no se procuraba ni la salvaguarda de derechos, ni una garantía frente a la indefensión. Indicativas de esta doble intencionalidad, propia de muchas de las mujeres pleiteantes, son las «cartas de apartamiento de palabra» conservadas en los archivos notariales. Estos documentos, cuyo valor ha sido destacado por investigadoras como María José de la Pascua ${ }^{47}$, evidencian cómo las demandas por incumplimiento de palabra no siempre referían experiencias y prácticas ajustadas al modelo, al tiempo que refrendan la persistencia de una cultura más tolerante a la sexualidad prematrimonial y una débil implantación de los decretos tridentinos. En la misma línea, son dignos de mención los procesos que incluyen la escritura de desistimiento de quienes habían interpuesto la demanda. Se trataba siempre de litigios de corta duración, prueba de la escasa intención de las querellantes de continuar litigando una vez hubieran acordado con la parte contraria el precio de su silencio. Cuantía cierta, pese a no aparecer expresada en estas escrituras; y pese a las fórmulas establecidas, de esta forma: que se desiste de libre y espontánea voluntad, sin apremio ni fuerza de persona alguna, ni por dádivas ni promesas que le hayan hecho, dado ni prometido ${ }^{48}$. Otra cosa sería la

Quaglioni, D. (Dirs.): Coningi nemeci. La separazione in Italia dal XII al XVII secolo. Bolonia, Il Mulino, 2000, pp. 15-94.

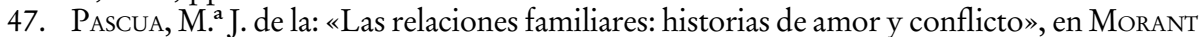
Deusa, I. (Coord.): Historia de las mujeres en España y América Latina, Vol. 2. Madrid, Cátedra, 2005, pp. 287-316.

48. Desistimiento de Ana, negra, esclava de Diego Báez, en el proceso contra Lorenzo Báez, esclavo del mismo amo. Dice hacerlo por cuando está bien informada de su justicia, por haberse aconsejado de personas de ciencias y conciencias, que por ello sabe no le conviene seguir la causa aunque lo pudiera hacer. AGAS, Sección Justicia, Serie matrimoniales, leg. 4306, exp. $24,1645$.

(C) Ediciones Universidad de Salamanca / ®@ Stud. his., H. ${ }^{a}$ mod., 38, n. 2 (2016), pp. 55-105 
MARTA RUIZ SASTRE Y MARÍA LUISA CANDAU CHACÓN

EL NOVIAZGO EN LA ESPAÑA MODERNA Y LA IMPORTANCIA DE LA «PALABRA». TRADICIÓN Y CONFLICTO

realidad marcada por las necesidades que ponían -y cobraban- el precio de la supuesta virginidad; y de la honra.

Tales usos de la justicia nos permiten comprobar cómo aquellos tribunales sirvieron de espacios en los que presentar, estratégicamente, los argumentos que favorecieran el triunfo de los propios intereses. Existiera, o no, verdad de fondo, lo cierto es que las demandas, confesiones y alegatos de las partes sobre el intercambio de la palabra de casamiento y posteriores encuentros sexuales se constituían hábil e inteligentemente -también en lo que al aspecto dramático se refiere, en la escenografía y en la conveniencia de ciertos silencios ${ }^{49}$ - a fin de ganar el favor de los jueces y obtener una sentencia favorable.

Puede decirse que las estrategias desarrolladas en sede judicial en torno a las causas por incumplimiento de palabra de casamiento se orientaron fundamentalmente en dos direcciones. Primero, hacia las construcciones sociales relativas a los dos géneros. Hombres y mujeres, demandados o demandantes, participaron en los contenciosos cincelándose a sí mismos, adaptando sus discursos a los estereotipos sexuales de la época para garantizar -en la medida de lo posible- la obtención de los fines perseguidos. La mujer, descrita a sí misma como honrada y de conducta intachable, subrayará la pasividad de su conducta, recordando cómo había reservado su virginidad a quien le ofreciese palabra de matrimonio; en tanto los hombres, lejos de tener que justificar su sexualidad -pues su honor no se basaba en la integridad y la pureza del cuerpo-, lanzarán piedras sobre la reputación de la mujer al tiempo que rechazarán la existencia del compromiso. Y segundo, siguiendo la línea de lo propugnado en Trento, hacia la defensa del libre consentimiento de los jóvenes en cuestiones de matrimonio por encima de cualquier imposición paterna o determinismo familiar.

Las «palabras» desatendidas hubieron de ser, por lógica, más numerosas. Promesas frecuentemente quebradas por la oposición familiar al enlace y, por otro lado, imposibles de reclamar en casos en los que el supuesto embaucador marchara sin dejar ni rastro ni noticias. Promesas, asimismo, desistidas de mutuo acuerdo o «negociadas» entre familias. En cualquier caso, promesas que no dejaron huella documental.

49. Burghartz, S.: «Tales of Seduction, Tales of Violence: Argumentative Strategies before the Basel Marriage Court», German History, 17, 1999, pp. 41-56.

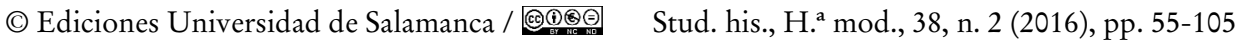


MARTA RUIZ SASTRE Y MARÍA LUISA CANDAU CHACÓN

EL NOVIAZGO EN LA ESPAÑA MODERNA Y LA IMPORTANCIA DE LA «PALABRA». TRADICIÓN Y CONFLICTO

4. El embarazo de los parientes. Raptos, secuestros, matrimonios ClanDESTINOS Y MATRIMONIOS POR SORPRESA

Padres e hijos en el mundo hispánico ${ }^{50}$. Los conflictos marcados por la elección del futuro cónyuge-que tanto dieron que hablar en la Europa católica y protestante, en la literatura moral como en la normativa y leyes de los Estados- propiciaron caminos y fórmulas - no todas lícitas- de solucionar los enfrentamientos. El recuerdo continuo al cuarto mandamiento -en todos los espacios de la Cristiandad- buscaba conciliar los deseos de los progenitores y las inclinaciones de los hijos. A medio camino entre la obediencia, el afecto y la sumisión, los consejos de los moralistas reclamaban -utópicamente- a los padres dejar de un lado intereses exclusivamente materiales o de linaje y patrimonio, buscando lo mejor para sus hijos y, a los hijos, respetar y valorar las decisiones paternas. Bastantes más claros los protestantes que los católicos, la defensa de la libertad de elección post conciliar, aquí tratada, quedaba a veces en la ambigüedad de las contradicciones: respeto a los mayores y respeto, también, a las necesidades de consentimiento. ¿Y cuando ambas se contradecían? Los escritores, los humanistas y los tratadistas llamaban al «acuerdo»; pero, de optar, ninguno favorecía la elección de los hijos al margen o en oposición a la voluntad paterna. Los ejemplos de doncellas de Luis Vives y, posteriormente, de los moralistas de la segunda mitad del Quinientos y del Barroco, alababan la postura de las que aceptaban la voluntad paterna, pero, como recorrido de círculo, suponían que los intereses familiares buscaban el mejor destino para los hijos ${ }^{51}$. Y ¿qué decir de los escritores que apologizaron las medidas de Carlos III? Amorós, entre ellos ${ }^{52}$. Las voces de finales del XVIII, casi siempre civiles, elogiarían las pragmáticas reales. Cambiaban los tiempos.

Volviendo al Quinientos, y según comentamos con anterioridad, la Iglesia católica preveía los conflictos. Y ofrecía diversas fórmulas en casos irresolubles en los que la mediación de familiares, curas o vicarios no funcionase. La protección del ordinario diocesano, la orden de depósito en casas conocidas o incluso en la parroquia, y por el vicario, la exploración en dichos espacios de las voluntades y la-digamos-investigación consecuente de las causas de la oposición encontraron

50. Con tal título, el libro coordinado por Usunariz, J. M. y García Bourrellier, R., editado en Madrid, Síntesis, 2008.

51. Morant Deusa, I.: Discursos de la vida buena. Madrid, Cátedra, 2002, (el capítulo correspondiente de la historia de las mujeres); CANDAU, M. L.: «El amor conyugal, el buen amor. Joan Estevan y sus 'Avisos de casados'», Studia Historica. Historia Moderna, 25, 2003, pp. 311-349.

52. Discurso en que se manifiesta la necesidad y utilidad del consentimiento paterno para el matrimonio de los hijos y otros deudos. Madrid, 1777.

(C) Ediciones Universidad de Salamanca / ®@ Stud. his., H. ${ }^{a}$ mod., 38, n. 2 (2016), pp. 55-105 
MARTA RUIZ SASTRE Y MARÍA LUISA CANDAU CHACÓN

EL NOVIAZGO EN LA ESPAÑA MODERNA Y LA IMPORTANCIA DE LA «PALABRA». TRADICIÓN Y CONFLICTO

cobijo en las antiguas diócesis. Recordaremos la curiosa experiencia de las amonestaciones del pintor Bartolomé Esteban Murillo en febrero de 1645; al tiempo de las mismas, observaría el fiscal las aflicciones de la novia; preguntándole acerca de su voluntad, y de la causa de sus llantos y gestos de nerviosismo, e intuyendo sospechas evidentes de forzamiento, anotaría su impresión negativa a la concesión de la licencia para contraer matrimonio. Una semana más tarde, tras haber permanecido en casa conocida, confesado y comulgado, cambiaría de parecer, alegando su turbación al hecho de verse sola, en tales trances. Y se procedería a la realización del matrimonio ${ }^{53}$.

En otra dirección, las oposiciones familiares a la celebración de un matrimonio deseado por los contrayentes abrían puertas a caminos tradicionales y -según qué casos- contemplados por la ley eclesiástica. Así, la fórmula denominada «llevarse a la novia» venía a ser la expresión popular de su extracción de la casa familiar, por el alguacil eclesiástico y por mandato del juez de la Iglesia. De un lado se solicitaba la extracción, que realizarían las autoridades eclesiásticas, quienes decidían su oportunidad; de otro, se les otorgaba un tiempo de reflexión -casi siempre breve- en casas «que la abonaban», en el que la sacada -con tal término en la documentación sevillana- habría de aclarar definitivamente su voluntad. Esta fórmula contemplada y contenida en los expedientes de matrimonios ordinarios que planteaban conflictos -luego solucionados-convivía, al parecer, en algunas diócesis con la denominada de rapto y asimismo sacar a la novia, procedimiento usado en casos de mayor conflicto en los que el pretendiente realmente (aunque con el beneplácito de la mujer) la sacaba del domicilio familiar. La recuperación de un honor que quedaba en entredicho haría necesario el matrimonio, como mal menor que los parientes habrían de aceptar. A su vez, el rechazo a los pretendientes por parte de los progenitores podía generar un insulto a la dignidad según de quién y el consecuente remedio de reparo consistente en «sacar a la novia» ${ }^{54}$. Como se usaba -y no solo como señal de fogosidad juvenil- para acelerar un compromiso o

53. Sobre este «suceso» que por la rápida solución no generaría pleito -y por tanto no configuraría expediente del tipo de nuestro estudio- ya informaron en su día Santiago Montoto y Diego Angulo, en sus obras clásicas sobre el pintor. En la actualidad hemos accedido al expediente, base de un trabajo posterior.

54. Tal se recoge en CASEY, J.: «El matrimonio clandestino en Andalucía en la época moderna», en Familia y sociedad en el reino de Granada durante el Antiguo Régimen. Granada, 2008 (publicado anteriormente en francés en 1985), pp. 15-35, referencia en p. 22. En 1774, don Francisco Sánchez Gutiérrez Vigil, hidalgo de Sigüenza, rechazado como pretendiente de la hija del secretario municipal de Córdoba, expresaría por escrito su indignación con estos términos: dando motivo a que por el vulgo... se sospeche contra mi honor alguna desigualdad o defecto de mí. Para ello recurriría a sacar a la novia.

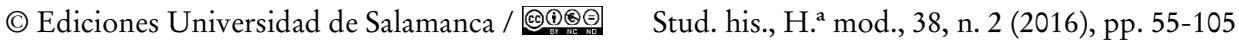


MARTA RUIZ SASTRE Y MARÍA LUISA CANDAU CHACÓN

EL NOVIAZGO EN LA ESPAÑA MODERNA Y LA IMPORTANCIA DE LA «PALABRA». TRADICIÓN Y CONFLICTO

rechazar a otros pretendientes que, obviamente, tras el secuestro y la sospecha de la pérdida de la honra, desestimarían la propuesta. El rapto, entonces, constituía una fórmula de acelerar o de convencer, salvando (solo en las formas) el consabido honor doméstico. Y más ejemplos. Aún en el xIX, se producían «arreglos» formales como estos: es bien conocido el episodio de sabiduría doméstica redactado por Alcalá Galiano; reacia a emparentar con un comerciante por el matrimonio de su hija, la madre del escritor solicitó a su futuro yerno el depósito de la novia en casa del vicario; solo entonces daría su consentimiento, a sabiendas de que tal suceso haría ver -en sus círculos de sociedad- una oposición solo franqueada por el depósito de la joven en cuestión. De tal manera -expresaba-salvaba su honor ${ }^{55}$.

La Andalucía oriental demostraba ser más propicia a las fórmulas del rapto o el «sacar a la novia», según demostró hace décadas James Casey para la archidiócesis de Granada. También en la Ibiza de la segunda mitad del xviII, la fórmula del secuestro, teóricamente ordenada por el Provisor o Juez eclesiástico, en realidad orquestada por uno de los dos comprometidos (mediando esponsales previos) y cuando alguno de ellos no quería cumplir la palabra, fue fórmula utilizada para sustraer sobre todo a las novias alejándolas de presiones familiares contrarias al compromiso o incitándolas a reflexionar, según dijimos, a fin de cumplir una promesa anterior. Se les depositaba entonces en casas convenientes «al objeto de explorar su voluntad y su ánimo» ${ }^{56}$, comprobándose su disponibilidad o la veracidad de las coerciones. El objetivo, pese a su inicial significación, era precisamente la defensa de la voluntad de estas mujeres a veces obligadas, bien a rechazar un matrimonio, bien a rendirse a uno concertado por los padres de familias. Hace años que los Demerson describieron el proceso de convivencia que los secuestros ibicencos supusieron para estas mujeres en otras familias en donde -se esperabareflexionarían en la cotidianeidad de los días establecidos, su vida futura y su elección. ¿Se aseguraba así la libertad de consentimiento? Claramente en algunos $\operatorname{casos}^{57}$,

55. Alcalá Galiano, A.: Memorias. Madrid, 1886. T ${ }^{\circ}$ I. P. 355. Recogido en Casey, J.: «El matrimonio clandestino...», cap. cit., p. 24. Haz que sea depositada por el vicario. Después de esto yo daré mi consentimiento, pero al menos mis amigos verán que he hecho todo lo posible por salvaguardar el honor de mi familia.

56. Demerson, J. y Demerson, P. de: Sexo, amor y matrimonio en Ibiza durante el reinado de Carlos III. Mallorca, El Tall. 1993, p. 168.

57. Más claramente en la Ibiza del XviII. Los casos descritos en la obra ya citada presentan una mayor libertad, aun bajo secuestro. Es el caso, en 1791, de la joven Antonina Riera, en 1791, secuestrada por orden del vicario ante su negativa a cumplir la palabra dada. Depositada en casa de una familia del lugar, su persistencia y lo que entendemos como la humillación pública del novio acabaría por concederle la libertad. Significativas son las palabras de 1 pretendiente: considerando no serme decoroso ni conveniente pretender mujer que no me tiene voluntad. Demerson, J. y Demerson, P. de: op. cit., p. 164.

(C) Ediciones Universidad de Salamanca / ®@ Stud. his., H. ${ }^{a}$ mod., 38, n. 2 (2016), pp. 55-105 


\section{MARTA RUIZ SASTRE Y MARÍA LUISA CANDAU CHACÓN EL NOVIAZGO EN LA ESPAÑA MODERNA Y LA IMPORTANCIA DE LA «PALABRA». TRADICIÓN Y CONFLICTO}

aunque no son fórmulas extendidas en muchas áreas; ni sabemos en qué medida influyeron los desistimientos, las presiones o las elecciones individuales. $\mathrm{Ni}$ si los alejamientos obligatorios de los pretendientes por cuya causa se les «secuestraba» se cumplieron. Pero lo cierto es que la fórmula existía; la causa -el ejercicio de la fuerza- también.

Entendemos que los términos son susceptibles de variación según las diócesis. En Zaragoza, los pleitos por incumplimiento de palabra de matrimonio se incluyen bajo el término de jactancias, acción atribuible a quienes, habiendo realizado esponsales -y cópula carnal- se resistían a cumplirla, no evitando jactarse de ello o reconocerlo ${ }^{58}$. En la archidiócesis de Sevilla, tales vocablos hacen referencia únicamente a quienes presumieron de su incumplimiento, reconociendo existencia previa de «trato»o palabra. De este modo, en los índices de la primera mitad del XVIII computamos un total de 33 pleitos por jactancia (entre 1725 y1762), que las «resultas» del oficio II presentaban aparte de las propias demandas por incumplimiento de promesa de casamiento, que casi alcanzaban los 1400 y solo ante uno de los dos oficios vigentes. Parece entonces que en esta parte de Andalucía Occidental, la jactancia se atenía más a lo que el derecho definía del siguiente modo:

En el lenguaje forense se llama demanda de jactancia la que se interpone para obligar a otro, que se jacta de tener derechos contra el demandante, a que los ejercite en el juicio correspondiente. Jactancia es, pues, la manifestación que uno hace de cosas que pueden causar a otro algún perjuicio o menoscabo en su estado personal o en su reputación, En estos casos... el agraviado puede solicitar del juez que obligue al jactancioso a entablar demanda a fin de que pruebe la verdad de sus manifestaciones o a desdecirse judicialmente de ellas o a darle la satisfacción que corresponda (...). El origen de la demanda de jactancia hállase en la ley 46, tít. II de la Partida tercera ${ }^{59}$.

Siguiendo con la diferente significación de los términos citados -lo que a veces induce a confusión-, el sacar a la novia no tenía connotaciones negativas obteniendo licencia y orden del Provisor; en tanto el rapto -sin permisos- se utilizaba como mal menor en Andalucía oriental, donde continuaría como fórmula hasta no hace mucho tiempo ${ }^{60}$. En la archidiócesis de Sevilla, las solicitudes relacionadas con la primera de las fórmulas referidas se incluían en los expedientes de matrimonios ordinarios, precediendo lógicamente a la toma de amonestaciones.

58. Baldellou Monclús, D.: «La posición de la mujer...», cap. cit.

59. Diccionario Enciclopédico Hispano-americano. Barcelona, Montaner y Simón, eds. 1892. Tomo XI, p. 28.

60. En la zona almeriense próxima a Murcia no pocas veces se utilizaba la fórmula como sistema de evitar el gasto de las bodas. Las fuentes son orales. 
MARTA RUIZ SASTRE Y MARÍA LUISA CANDAU CHACÓN

EL NOVIAZGO EN LA ESPAÑA MODERNA Y LA IMPORTANCIA DE LA «PALABRA». TRADICIÓN Y CONFLICTO

No han de confundirse con los pleitos matrimoniales pues estos se constituían en función de una demanda, en tanto aquellos -las licencias para contraer matrimonio, sacando a la novia-, conformaban un expediente común -ordinario- de matrimonio, con ciertas complicaciones a resolver. Sin pleitos o con antiguos pleitos desistidos. Un ejemplo y ejemplo notable: el casamiento de Luisa Ignacia Roldán, conocida como La Roldana, artista sevillana, hija de don Pedro Roldán, que llegaría a ser escultora de cámara de Carlos II y posteriormente de Felipe $\mathrm{V}^{61}$. Con solo 17 años (según consta en su expediente) contraería matrimonio con un antiguo aprendiz del taller de su padre-Don Luis Antonio de Arcos-sin su consentimiento. Para ello el novio, y en su nombre su apoderado, solicitará al juez de la iglesia licencia para contraer matrimonio pese a la oposición paterna, presentando prueba testifical de la existencia de palabra de casamiento entre ambos, una palabra otorgada días antes ante testigos buscados al efecto; no era por tanto un hecho casual, sino concertado y premeditado entre los novios. Con tales testimonios, el Provisor ordenará, vía alguacil eclesiástico, extraer a la novia «de allí donde fuere hallada» para explorar su voluntad. Una vez declarada la ausencia de fuerza, base del mutuo consentimiento, la artista sería «depositada» en casa de uno de los testigos, de donde saldría nuevamente a declarar su voluntad; de este modo y pese a la ausencia de consentimiento, en diciembre de 1671, contraerían matrimonio tras la otorgación de la licencia del juez de la Iglesia. No hay pleito, solo oposición del padre, más claramente manifiesta en su ausencia al tiempo de la celebración del matrimonio ${ }^{62}$. Y como este existieron otros. En todos, las fórmulas serán idénticas: novios contrariados, apoderados que los representan, palabras de casamientos teatralizadas ante testigos, pruebas consecuentes testificales, solicitudes de exploración, mandatos del Provisor de sacar a la novia, declaraciones de libertad de consentimiento, depósitos breves (a veces dos días), dispensa de amonestaciones y otorgación de licencias: que los conflictos entre padres e hijos no siempre se inclinaron por la tónica del cuarto mandamiento.

Por tanto, en cualquiera de los casos mencionados, estos documentos prueban la existencia de enfrentamientos, por causa de oposición familiar, así como de las posibilidades de resolución; darán aún que hablar en los tribunales eclesiásticos

61. Fue editado por Montoto, S.: «El casamiento de la Roldana», Boletín de la Academia Sevillana de Buenas Letras, 15, 1920, pp. 113-120. Hemos podido consultar el original en el Archivo General del Arzobispado de Sevilla.

62. No existen pruebas documentales de las causas de oposición paternas, no solo al enlace de Luisa Ignacia, sino también de otras dos hijas del escultor. Sus biógrafos refieren causas diversas y posibles: control de la competencia artística, escasa fiabilidad del yerno, etc. Los expedientes no incluyen en estos casos las causas reales; únicamente ser el embarazo paterno razón de la no celebración de un matrimonio querido por los contrayentes. 
MARTA RUIZ SASTRE Y MARÍA LUISA CANDAU CHACÓN

EL NOVIAZGO EN LA ESPAÑA MODERNA Y LA IMPORTANCIA DE LA «PALABRA». TRADICIÓN Y CONFLICTO

hasta fines del xviII. Para entonces las mencionadas pragmáticas de 1776 y 1803 establecerían la imperiosa necesidad del consentimiento paterno, inmiscuyéndose así las autoridades civiles en asuntos hasta entonces eclesiásticos. Pero hasta tales tiempos, ¿qué podían hacer los progenitores para manifestar su postura?: los pleitos matrimoniales eclesiásticos atestiguan la existencia de demandas de «embarazo paterno» a los matrimonios que los hijos pretendían contraer. Obvio es resaltar que la mayoría de tales impedimentos atañía a pretensiones de casamientos «desiguales». En el arzobispado hispalense, los citados años comprendidos entre 1707-1762 -oficio II- incluyeron mención a 52 expedientes de pleitos por tal causa. Y contenían algunas prácticas parecidas al citado «rapto», con evidente connotación negativa. De este tenor:

El expediente extractado de don Juan Joseph de Álvarez, de Morón de la Frontera (Sevilla), fechado en 1710, lo fue con el título siguiente: Don Juan Joseph de Álvarez con doña Ana Romero, sobre sacarla para contraer matrimonio. Obviamente porque no poseían el permiso paterno ni el eclesiástico. Más claramente en 1712-1713, el tribunal del Juez de la Iglesia admitiría como tal la demanda contra Jerónimo Morillas; su expediente sería resumido como Jerónimo Joseph de Morillas con doña Catalina de Godoy, sobre contraer matrimonio, a que salió Juan de Godoy su padre, poniéndole impedimento. Morón, 1712-171363. Y los «embarazos» de los parientes (padres, madres viudas, hermanos o cuñados) a los matrimonios de sus familiares generaron en el xvirI (antes de la Pragmática Real) pleitos eclesiásticos en donde se dirimían las cuestiones relacionadas con las causas de dichos impedimentos, por si fuesen «frívolas» o estuviesen basadas en razones de peso. He aquí otros ejemplos: Autos matrimoniales de don Pedro Román Meléndez, padre de Don Alonso Román Meléndez, sobre éste querer casarse contra la voluntad de su padre (Utrera, 1737-1741). Y también: Que se le ponga nibil transeat para que no se case. Por doña María Márquez, viuda de Pedro de Obella, pretende casarse, a que salió Don Luis de Acuña, pretendiendo se le ponga nibil transeat (Sevilla, 1737-1741). Asimismo: Cristóbal Morón con Leonor Tello, sobre contraer matrimonio a que salió Pedro Pérez, padre de la susodicha. Morón (1734/1736). En el fondo, se trataba de procesos que pueden ser analizados desde dos ópticas: intentos de casamiento sin consentimiento paterno ni licencia eclesiástica -lo que les diferencia de los ejemplos anteriores- y manifestaciones de las causas esgrimidas por los parientes para su obstaculización.

A raíz de la Real Pragmática de 1776, en vigor en América colonial desde 1778, proliferaron los denominados juicios de disenso. En Canarias han sido

63. AGAS. I/ Sección Justicia, Serie Pleitos, leg. 10.871 (antiguo 1020). 
MARTA RUIZ SASTRE Y MARÍA LUISA CANDAU CHACÓN

EL NOVIAZGO EN LA ESPAÑA MODERNA Y LA IMPORTANCIA DE LA «PALABRA». TRADICIÓN Y CONFLICTO

estudiados por M. E. Monzón para Tenerife (1776-1802) ${ }^{64}$ ante las autoridades locales; en la América colonial su fruto historiográfico ha sido evidente entre los historiadores del matrimonio como espacio de $\operatorname{conflictos}^{65}$. Su objetivo: obtener la licencia familiar para poder contraer matrimonio, una vez que existía prueba documental de la palabra dada y de los esponsales asimismo contraídos. La propia existencia del pleito manifestaba entonces la evidencia del enfrentamiento entre padres e hijos. Con una diferencia: ahora eran los hijos (generalmente varones, pero también mujeres) los que podían llevar a los padres ante los tribunales a fin de obtener el citado permiso, un permiso requerido -y esto es lo relevante- por el

64. Monzón Perdomo, M. E.: «La familia como espacio de conflicto. Los juicios por disenso matrimonial en Tenerife», Anuario de estudios Atlánticos, 60, 2014, pp. 413-450.

65. Porro, N.: «Conflictos sociales y tensiones familiares en la sociedad virreinal rioplatense a través de los juicios de disenso" Boletín del Instituto de Historia Argentina y Americana, 26, 1980, pp. 361-393; IDEM, «Los juicios de disenso en el Río de la Plata: Nuevos aportes sobre la aplicación de la Pragmática de hijos de familia» Anuario Histórico y Jurídico Ecuatoriano, 5, pp. 193-229. IDEM, «Extrañamientos y depósitos en los juicios de disenso», Revista de Historia del Derecho, 7, 1985, pp. 123-150. Lavrin, A. (Ed.): Sexuality and Marriage in Colonial Latin America. Lincoln \& Londres, University of Nebraska Press, 1989; SeEd, P.: To Love, Honor, and Obey in Colonial México. Conflicts over Marriage Choice 1574-1821, Stanford, Stanford University Press, 1988; Rípodas ARDANAz, D.: El matrimonio en Indias. Realidad social y regulación jurídica. Buenos Aires, Conicet, 1997,pp. 135-56; Celton, D.: «Selección matrimonial y mestizaje en Córdoba», en III Jornadas de Historia de Córdoba, Junta Provincial de Historia de Córdoba, Córdoba, 1990; Socolow, S.: «Parejas bien constituidas. La elección matrimonial en la Argentina colonial. 1778-1810», Anuario del Instituto de Estudios Históricos y Sociales, Tandil, 1997; Fernández, M. A.: «Familias en conflicto: entre el honor y la deshonra», Boletín de Estudios de Historia Argentina y Americana, 1999, pp. 7-43; MARre, D.: «La aplicación de la Pragmática Sanción de Carlos III en América Latina: una revisión», Scipta Vetera. [http//: www.ub.es.geocrit/sv-22htm (17-10-2002)]; GHIRARDI, M.: Matrimonios y familias en Córdoba. Prácticas y representaciones. Córdoba: Universidad Nacional de Córdoba, 2004; Carballeda, A.: «Género y matrimonio en Nueva España: las mujeres de la elite ante la aplicación de la Pragmática de 1776», en Gonzalbo Aizpuru, P. y Ares Queija, B. (Coords.): Las mujeres en la construcción de la sociedad Iberoamericana.Mexico, El Colegio de México-FCE, 2005; GonZalbo Arzpuru, P.: «Conflictos y rutinas en la vida familiar», en Gonzalbo Aizpuru, P.: (Coord.): Historia de la vida cotidiana en México. Sevilla, México, Escuela de Estudios Hispano-Americanos- El Colegio de México, 2004; El siglo XVIII entre tradición y cambio, t. III; GÁLVEZ RuIZ, M. T.: «La historia de las mujeres y de la familia en el México Colonial», Chronica Nova, 32, 2006, pp. 67-93; IDEm: «Desórdenes y escándalos públicos y notorios en comunidades de México Colonial», en ARIAS De SaAvedra, I. (Coord.): Vida cotidiana en la España de la Ilustración. Granada, Universidad, 2012, pp. 397-424; GonZÁlez GómEZ, Y. M.: Conflicto, violencia sexual y formas de transgresión moral en el obispado de Concepción, 1750-1890. Tesis doctoral inédita. Departamento de Historia II. Universidad de Huelva, 2011; Falcón Gómez SÁnchez, F. J.: «El matrimonio clandestino de María Isabel Cavero. Conflicto entre amor, leyes e iglesia, en Truxillo del Perú, a fines del siglo XviII (1794)», Nuevo Mundo Mundos Nuevos, Debates. [http://www. nuevomundo.revues. org/3352]; Cicerchia, R.: Historia de la vida privada en la Argentina. Buenos Aires, Troquel, varios vols.

(C) Ediciones Universidad de Salamanca / ®@ Stud. his., H. ${ }^{a}$ mod., 38, n. 2 (2016), pp. 55-105 
MARTA RUIZ SASTRE Y MARÍA LUISA CANDAU CHACÓN

EL NOVIAZGO EN LA ESPAÑA MODERNA Y LA IMPORTANCIA DE LA «PALABRA». TRADICIÓN Y CONFLICTO

Estado, que no la Iglesia. Claramente para evitar (sobre todo en parte de América) los matrimonios desiguales, normalmente contraídos de manera «presunta», lo que revela la buena salud de los esponsales y del valor de las promesas efectuadas de casamiento ${ }^{66}$. Nuevamente (en la Península y sobre todo en algunos espacios argentinos y novohispanos) de los matrimonios sin consentimiento ${ }^{67}$. Los tribunales eclesiásticos, a su vez, entenderían de tales pleitos al serles ahora preciso, por orden civil, exigir a los contrayentes las licencias paternas. Como evidente contradicción de los tiempos, a fines del xviII, más de un siglo después, Luisa Ignacia Roldán, la Roldana, no habría podido efectuar el matrimonio; le habría faltado el consentimiento paterno.

Los juicios por disenso reflejan, también, el uso de un mismo discurso entre las partes. No estamos ante padres que defienden casamientos ventajosos, o hijos que saben y reconocen sus diferencias sociales y abogan, por ello, a causas sentimentales. Independientemente del valor real de las emociones, nos hallamos ante contendientes que esgrimen la igualdad de condición desde distintas ópticas. Sabiendo que la Real Pragmática contemplaba la diferencia y las ofensas al honor familiar como esenciales en la negativa del padre de familia, los pretendientes argüirán -pese a las argumentaciones de los progenitores- ser de igual condición. Expresiones como «somos iguales» se reiteran entre los «novios» tinerfeños ${ }^{68}$. En menor medida, pero no de forma infrecuente, los padres manifestaron su oposición por causas de orden moral: una mala fama del pretendiente, o un pasado de amantes o sospechas de otros compromisos en otras tierras argumentaron las negativas de padres celosos del bienestar de sus hijas y del honor familiar; que no toda oposición procedía, exclusivamente, de un interés material.

Desde el punto de vista de quienes ejercían la autoridad familiar-padres, hermanos mayores- el juicio por disenso constituía el ejercicio tradicional de su oposición. Ante matrimonios inminentes, se presentaban para obtener la licencia que impidiese la ceremonia eclesiástica y argumentaban razones de desigualdad, bien social o bien, asimismo, racial; en las Islas como en América. Porque si bien las Pragmáticas posibilitaron a las autoridades civiles su incursión en los asuntos matrimoniales, la continuidad de las competencias eclesiásticas -o los cruces de autoridad-generaron no pocos conflictos. La advertencia sin embargo procedía

66. En el sur de Chile, sin embargo, la tesis doctoral de Yéssica González no encontró evidencia de estas promesas en el obispado de Concepción. GonzÁlez Gómez, Y.: op. cit.

67. A resaltar GHIRARd, M.: Matrimonios y familias en Córdoba. Prácticas y representaciones. Córdoba, Centro de Estudios Avanzados, Córdoba, Universidad Nacional de Córdoba, 2004.

68. Monzón Perdomo, M. E.: «La familia», art. cit., p. 430.

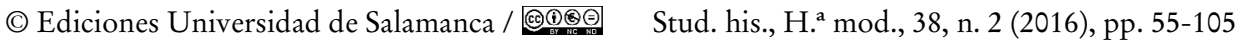


MARTA RUIZ SASTRE Y MARÍA LUISA CANDAU CHACÓN

EL NOVIAZGO EN LA ESPAÑA MODERNA Y LA IMPORTANCIA DE LA «PALABRA». TRADICIÓN Y CONFLICTO

del Estado: la posibilidad de desheredamiento se perfilaba como fuerza motriz y cambiaría no pocas decisiones al tiempo de los juicios por disenso.

Hijos que se quieren casar y padres que se oponen a sus deseos. Compromisos incumplidos, esponsales contraídos... las peculiaridades del proceso matrimonial y la manifestación más clara de la relevancia de los verba de futuro y de las, casi siempre, relaciones carnales anejas, se manifestaron, también, en los expedientes efectuados para obtener, justamente, la libertad de esponsales. La fuerza del compromiso obligaba a su desistimiento formal, de haber «mutuo acuerdo», ante los tribunales de la Iglesia. Los trabajos -ya clásicos- de Jean Louis Flandrin analizaron a finales de los setenta y comienzos de los ochenta tales procesos de ruptura; su evolución apuntaba -en la región francesa de Troyes-, ya en la segunda mitad del siglo xvir, nuevas formas en el concierto de las relaciones sociales y, por tanto, del matrimonio. En efecto, las causas alegadas por quienes querían desistirse de la palabra mutuamente otorgada eran -argumentaban- la falta de inclinación o el enfriamiento de la amistad entre los antiguos «novios» ${ }^{69}$. Como apuntara en su día el historiador francés, lo llamativo no era el argumento; lo significativo radicaba en la comprensión y aceptación de los tribunales eclesiásticos. En la archidiócesis de Sevilla, las peticiones de libertad de esponsales fueron mínimas. Entre 1715 y 1762, el oficio II cursaría 17 demandas de «disposición de sus personas», mayoritariamente solicitadas en común: 14 de los citados 17 lo realizarían de mutuo acuerdo. De esta forma: Para disponer de sus personas. Sevilla, Antonio Luis y María de Mata, 1737-1741. O bien Juan Romero Soria y Agueda Perea sobre que se les conceda licencia para disponer de sus personas y contraer matrimonio (Aznalcóllar, entre 1737 y 1741).

Sabemos de la relevancia de los esponsales, de la fuerza del compromiso y del valor de la palabra dada, cuando esta se materializaba sexualmente. A veces para forzar mutuamente un matrimonio, a veces para obligar a uno de los posibles contrayentes. Porque siempre existía la posibilidad del abandono; avisada por los moralistas, siguiendo los postulados de Trento, tales posibilidades se materializaron en la multitud de demandas por incumplimiento de promesa de casamiento; la pervivencia del valor del honor sexual conformador del destino de las mujeres, en su mayoría, y la dependencia para su futuro de la realización de un matrimonio conveniente necesitaban la erradicación de los matrimonios clandestinos, objetivo más o menos exitoso, considerando no solo su disminución, cuanto su cualidad. En el arzobispado hispalense, los únicos casos conservados

69. Flandrin, J. L.: La moral sexual en occidente: evolución de las actitudes y comportamientos. 2. ${ }^{a}$ Ed. Barcelona, 1984, (1. ${ }^{a}$ edición en francés, 1981), p. 99 y 103.

(C) Ediciones Universidad de Salamanca / ®@ Stud. his., H. ${ }^{a}$ mod., 38, n. 2 (2016), pp. 55-105 


\section{MARTA RUIZ SASTRE Y MARÍA LUISA CANDAU CHACÓN EL NOVIAZGO EN LA ESPAÑA MODERNA Y LA IMPORTANCIA DE LA «PALABRA». TRADICIÓN Y CONFLICTO}

muestran uniones clandestinas que en el XVII lo eran por huir de la solemnidad y en el XVIII por cuestión de formas. En la diócesis de Pamplona, los siglos XVI y XVII vieron incrementarse las demandas por incumplimiento de palabra (al ritmo de una población en aumento) y, al mismo tiempo, descender moderada, pero continuamente, los procesos por clandestinidad ${ }^{70}$. Realmente los estudios realizados ratifican la escasez de este tipo de pleitos seguidos ante los tribunales eclesiásticos. En el de Zamora, Francisco Javier Lorenzo Pinar constató únicamente 7 pleitos, y eso en el xvi (5\% del total de los litigios tramitados ante este tribunal), e Isidro Dubert reduce al 1,1\% los clandestinos que se hallaban tras los comportamientos prematrimoniales gallegos, claro que en tiempos de descenso generalizado de este tipo de procesos, como lo fue el XVIII ${ }^{71}$.

¿Cómo eran estos matrimonios ? $^{72}$ ¿Hasta qué punto las sociedades modernas habían asimilado las normas y los preceptos? Los ejemplos que traeremos a

70. Campo Guinea, M. J.: «Evolución del matrimonio en Navarra en los siglos xvi y xviI. El matrimonio clandestino", en Arellano, I. y UsunÁriz, J. M.: El matrimonio en Europa y el mundo hispánico. Siglos XVI a XVIII. Madrid, 2005, p. 202. La autora señala un crecimiento medio decenal de los procesos de palabra en casi un $25 \%$, y un descenso de un $3,8 \%$ de los procesos por matrimonio clandestinos.

71. Lorenzo Pinar, F. J.: «El tribunal diocesano», art. cit. Dubert García, I.: «Los comportamientos sexuales...», art. cit.

72. Hubo otros matrimonios, los denominados de conciencia o secretos, celebrados sin la observancia de todas las reglas de publicidad establecidas por la Iglesia, pero legales. En ellos intervenían el cura, los contrayentes y los testigos, pero se omitían las proclamas o se reducían a una, y podían realizarse fuera del templo sin la presencia de público. Eran autorizados por el Provisor episcopal en casos graves, cuando se temían vejaciones, oposición familiar, o podía haber por medio concubinatos. También en casos de lutos no cumplidos. Las disposiciones tridentinas adaptadas en las diferentes diócesis dieron lugar a las Constituciones Sinodales. Las del arzobispado hispalense (1609) dedican el tomo IV a los esponsales y los matrimonios. Del siguiente modo: la manera en que han de contraerse los casamientos en el Arzobispado, junto a otros aspectos relativos a la regulación del sacramento del matrimonio, a saber: que el cura no remita las moniciones aunque haya causa; que el juez de la Iglesia no dispensa en todas las tres moniciones, que cuando los curas amonestaren algunos para casarse o cuando los desposaren, no digan el señor mi señor; que los desposados se velen dentro de seis meses; dentro de qué tiempo se han de recibir las bendiciones nupciales; dónde y a qué hora se han de hacer las velaciones; la pena de los que cohabitaren en concertándose, antes de casarse; de qué manera se ha de dar licencia a los extranjeros para contraer matrimonio; que no se dé licencia para contraer matrimonio a los que no supieren la Doctrina Cristiana; cómo se han de recibir las informaciones de los que se quieren desposar; y contra los que se casan en grados prohibidos. Ruiz Sastre, M.: Las mujeres y los conflictos del matrimonio, op. cit., p. 359; CANDAU Chacón, M. L.: «Instrumentos de modelación y control: el concilio de Trento y las visitas pastorales. La archidiócesis hispalense, 1548-1609», en Martínez Millán, J. (Ed.): Felipe II (1527-1598). Europa dividida: la Monarquía Católica de Felipe II. Tomo III: Europa y la Monarquía Católica. Inquisición, religión y confesionalismo. Madrid, Parteluz, 1999, pp. 159-179. 
MARTA RUIZ SASTRE Y MARÍA LUISA CANDAU CHACÓN

EL NOVIAZGO EN LA ESPAÑA MODERNA Y LA IMPORTANCIA DE LA «PALABRA». TRADICIÓN Y CONFLICTO

continuación demostrarán cómo las familias de los siglos XVII y XVIII -algunas familias- habían adaptado a la práctica, y a su conveniencia, la esencia del sacramento.

En la Sevilla del Seiscientos, los dos únicos documentos que conservamos sobre pleitos matrimoniales de clandestinidad hacen referencia a una tipología peculiar; son los denominados matrimonios por sorpresa, aquellos que recogiera la literatura de ficción en la obra clásica de Los novios de Manzoni, ambientada, como es sabido, en la Italia del XVII. Las aclaraciones contenidas en la novela muestran a la perfección el conocimiento de los pretendientes. Recordémoslas:

Para celebrar una boda, hace falta, sí, el cura, pero no es necesario que él quiera; basta con que esté (...) hay que tener dos testigos muy despiertos y de acuerdo. Y se va donde el cura: la cosa está en cogerlo desprevenido, que no tenga tiempo de escaparse. El hombre dice: señor cura esta es mi mujer. La mujer dice. Señor cura éste es mi marido. Es menester que el cura lo oiga, que los testigos lo oigan; y el sacramento está hecho y tan sagrado como si lo hubiera hecho el mismo papa ${ }^{73}$.

Los expedientes del arzobispado hispalense conservados fueron incoados en los mismos tiempos. Década de los veinte, el primero en Jerez de la Frontera (1628), el segundo (1627) en la capital ${ }^{74}$. El primero, contraído por don Agustín Adorno, de quince años de edad, caballero de hábito -y con demanda por incumplimiento de palabra supuestamente otorgada a otra joven del lugar-, con doña Isabel Gaitán de Torres, de diecinueve. La razón: obviamente la huida del cumplimiento de la demanda interpuesta por la tercera en discordia, la presuntamente abandonada, doña Estefanía Benítez. El segundo, entre don Alonso Pérez de Guzmán y Leiva y doña Inés Coronado; el uno de dieciséis años, la otra de quince. Sin causa aparente que lo justificase, parece fruto de los planes familiares urdidos por la tía de la joven, aprovechando disgustos menores entre un padre estricto y un hijo adolescente que comentaba sus penas en casa conocida con un particular perfil: tres hijas casaderas, familia de condición media de menor estatus social, una tía manipuladora y unos padres ausentes. Las causas variaban, pero el incumplimiento de las formas repetía, de diversa manera, la ausencia de los requisitos tridentinos. En menor medida entre los jerezanos, quienes aprovechando una ceremonia bautismal

73. Manzoni, A.: Los novios. Madrid, Cátedra, 1985 (1. a ed. 1827). Cap. VI. Recogido en Ruiz SASTRE, M.: Las mujeres y los conflictos. Tesis doctoral citada, p. 362.

74. Ambos expedientes, analizados por RuIz SASTRE, M.: «Vidas unidas contra el discurso tridentino. El matrimonio clandestino en la Sevilla del Seiscientos», en Las mujeres y el honor en la Europa Moderna. Huelva, Universidad de Huelva, 2014, pp. 243-270. Candau Chacón, M. L.: «El matrimonio clandestino en el siglo Xvir: entre el amor, las conveniencias y el discurso tridentino", en Estudios de Historia de España VII. Buenos Aires, Instituto de Historia de España, 2006, pp. 175-203. 
MARTA RUIZ SASTRE Y MARÍA LUISA CANDAU CHACÓN

EL NOVIAZGO EN LA ESPAÑA MODERNA Y LA IMPORTANCIA DE LA «PALABRA». TRADICIÓN Y CONFLICTO

y otros actos a celebrar en la parroquia de ella-San Mateo-, se presentaron en tropel y tirando de la casulla del cura, don Juan Díaz, a mitad del oficio, el citado «novio» declaró: yo me otorgo por esposo y marido de doña Isabel Gaitán de Torres. $\mathrm{Al}$ instante respondería la mujer: yo también. En el caso sevillano, la «ceremonia» no usaría de la faz de la iglesia; en la casa de la joven, y con engaños, atrajeron al párroco de don Alonso, con falsos requerimientos de atenciones espirituales a una «malparida». Una vez en su interior, los dichos contrayentes, asegurándose la presencia de testigos, proclamaron su mutuo consentimiento, de este modo:

¡Señor don Sebastián! hablando al dicho cura, ¡usted es testigo y los presentes como doña Inés Coronado es mi mujer!, asiéndola de las manos y la dicha Inés dijo ...y los presentes cómo... Y don Alonso Pérez de Guzmán es mi marido ${ }^{75}$.

Las fórmulas son las mismas; las palabras, el gesto en los sevillanos de la unión de las manos como expresión del consentimiento; el cura sorprendido, el primero fingiendo no oír nada; el segundo a pleno grito para demostrar su desconcierto: ¡Señoras que me echan a perder, señoras que me destruyen! Pero ambas parejas no olvidaron los testigos ni la necesidad de consumar el compromiso: así, tras las palabras, conocedoras del valor del «trato» carnal, procederían a encerrase en sus respectivas salas para, a vista del público, expresar que mantendrían las relaciones requeridas para la validez del matrimonio. Los testigos además declararían los gritos de la doncella (tras ser desflorada), como las huellas visibles de la consumación del acto. En el fondo todos sabían que expresado el consentimiento, con testigos y con curas -a su manera- sería difícil invalidar el matrimonio que así quisieran contraer.

$¿$ Se trataba de matrimonios sentimentales, a la manera imaginada de las pasiones shakesperianas de mal fin? No necesariamente. En el caso sevillano, la trama femenina, representada en la figura de la tía de las jóvenes Coronado, aprovecharía las rabietas adolescentes de un chico de buena familia, visitante asiduo, para, primero, ofrecerle cobijo que le salvase del temor y los castigos del padre y, posteriormente, convencerle de la utilidad de su casamiento para lograr su independencia; en tales argumentos, todos asimilados y aceptados por el joven Alonso, faltaría únicamente la elección: cualquiera de las tres hermanas le valdría. Como en los cuentos, eligió a la menor, acorde con su edad, doña Inés, presta a cumplir lo que le conviniera. Pero a diferencia de los cuentos, las respuestas de Inés no tienen nada que ver con la pasión romántica. El interrogatorio a ambos, a fin de explorar la existencia o no del mutuo consentimiento, establece con rotundidad el significado del matri-

75. Declaración de doña María de Ugarte y Coronado. Candau Chacón, M. L.: «El matrimonio clandestino...», art. cit.

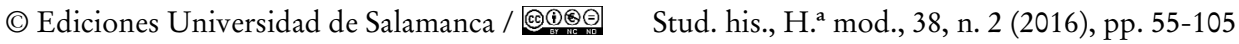


MARTA RUIZ SASTRE Y MARÍA LUISA CANDAU CHACÓN

EL NOVIAZGO EN LA ESPAÑA MODERNA Y LA IMPORTANCIA DE LA «PALABRA». TRADICIÓN Y CONFLICTO

monio desde una óptica de género. Ante las preguntas realizadas al varón acerca de su comportamiento y su elección, respondería: porque la quería. En tanto Inés aclaraba en confesión: y la dicha confesante se avino a ello porque su tía le dijo que era matrimonio que le convenía ${ }^{76}$.

Estos matrimonios titulados por sorpresa conjugaron bien el derecho natural y la expresión del consentimiento; se aseguraron de testimonios, de consumaciones y de expresión de sus libertades. Usaron del cura, lo que les diferenciaba de los esponsales privados pero, a sabiendas de las negativas de los párrocos por las penas establecidas en el derecho, lo usaron sorpresivamente. De ahí que uno negara haber oído nada y el otro proclamara su desconocimiento, razón que les valdría ser absueltos de cualquier actuación dolosa. A diferencia de ellos, los protagonistas, procesados en referencia a dos cuestiones -validez del sacramento y licitud-obtendrían en el primer caso sentencia positiva, en el segundo, el castigo competente. Por haberse hecho ante el párroco y testigos serían validados ambos matrimonios: el jerezano y el sevillano. Por no haber cumplido con los requisitos de solemnidad, serían penalizados en meses de destierro y penas pecuniarias, en el segundo de los expedientes básicamente contra la tía urdidora del plan. Lo que no les salvó de una permanencia en las cárceles arzobispales aun por pequeño periodo de tiempo. El matrimonio, entonces, resultaba válido. El castigo, intuimos, vendría de los opositores o desconocedores del acto. En el caso de los Guzmanes de Sevilla, la llegada de los alguaciles había sido avisada por los padres del muchacho, descubriendo a los jóvenes en el lecho conyugal; en el de los novios jerezanos, la jugada perjudicó, esencialmente, a quien demandara por palabra de casamiento; pues considerado válido el matrimonio posterior, desligaba y anulaba cualquier tipo de presunta promesa realizada con anterioridad. Los jóvenes del xvII -y sus familias- conocían a la perfección qué hacer para validar sus desposorios. Con una salvedad: ahora, en calidad de testigo, el sacerdote (el propio párroco) habría de estar presente; aunque fuera por sorpresa.

En el contexto de las Baleares, en tiempos en los que la isla de Ibiza aún pertenecía a la circunscripción eclesiástica de Tarragona, se produce el único matrimonio clandestino conservado documentalmente en la ciudad ${ }^{77}$. Pero las fórmulas, nuevamente, nos llevan a clasificarlo como matrimonio por sorpresa. En efecto, en marzo de 1759, dos jóvenes (Francisco Riera e Isabel Ribas) con sus testigos irrumpieron en la vicaría de la parroquia de san Antonio Abad, declarando ser matrimonio, teniendo (el varón) los brazos sobre las espaldas de la muchacha,

76. Confesión de Inés Coronado. Candau, M. L.: art. cit.

77. Demerson, J. y Demerson, P.: op. cit., pp. 198 y ss.

(C) Ediciones Universidad de Salamanca / ®@ Stud. his., H. ${ }^{a}$ mod., 38, n. 2 (2016), pp. 55-105 
MARTA RUIZ SASTRE Y MARÍA LUISA CANDAU CHACÓN

EL NOVIAZGO EN LA ESPAÑA MODERNA Y LA IMPORTANCIA DE LA «PALABRA». TRADICIÓN Y CONFLICTO

presentándola como su mujer. ¿Las causas?: como en Jerez un siglo y medio atrás, forzar el desistimiento de una palabra de casamiento pendiente contra el joven, promesa que no gozaba de expectativas ni antes ni después de contraído el matrimonio clandestino, por razones de desigualdad social. El proceso se alargará durante un año, tiempo en el cual, la abandonada (Antonina Vengut) y la nueva y matrimoniada esposa seguirán el litigio, cada una pretextando su validez; en tanto el disputado novio permanecía encarcelado. Las sentencias -como las anterioresrepetirán las mismas orientaciones: validez del contraído clandestinamente por ser en la iglesia, ante el párroco y con testigos, que en ello se seguía lo prescrito en Letrán (IV Concilio) y Trento. Pero al ser clandestino, castigarán a los contrayentes con penas espirituales y temporales; entre estas, el encarcelamiento de la joven, trabajos forzados para el varón en la fábrica parroquial, y el alcance de las costas. Prevalecía, entonces, el matrimonio, aun clandestino, celebrado coram parrocho et testigos, sobre los esponsales contraídos previamente, que no se negaban pero que se invalidaban. De ahí el castigo a los jóvenes, bastante más duros en esta ocasión que en los ejemplos anteriores, primero por existir prueba escrita de los esponsales, segundo porque ya en el XVIII las penas contra este tipo de matrimonios, aunque resultasen validados, se reforzaban. A fin de cuentas, entre prisiones antes y después de las sentencias, transcurrirían casi quince meses. Otra cosa es que tantos pesares les compensaran.

\section{Echado EN LA CAMA LE DIJO Y RESPONDIÓ QUE ESTABA CON SU MUJER. RECAPITULACIÓN}

El entendimiento común de los antiguos esponsales y de la otorgación de las palabras de futuro y presente generaban, de entrada, una relajación moral en la conducta de los supuestamente desposados que la Iglesia se esforzaba en desterrar. $\mathrm{Su}$ vigencia no solo demostraba ciertos niveles de fracaso institucional, sino la importancia del compromiso y sus ventajas «sexuales» anejas.

Guiándonos por la documentación al efecto -y dejando a un lado los registros parroquiales, básicos para el conocimiento de la ilegitimidad ${ }^{78}$, las fuentes disciplinarias nacidas del ejercicio disuasorio de la Iglesia facilitan hoy el estudio de las relaciones entre novios básicamente a través de las Visitas pastorales (Mandatos de las Resultas) y de los pleitos criminales y matrimoniales. Los primeros -Los libros de Visitas- abundaron en los «llamados» a los novios a contraer matrimonio, haciendo hincapié en el «excesivo» trato que los capitulados para casarse

78. Rey Castelao, O.: «Las mujeres gallegas y el honor», en Las mujeres y el honor en la Europa moderna. Huelva, Universidad de Huelva, 2014.

(C) Ediciones Universidad de Salamanca / ®@ Stud. his., H. ${ }^{a}$ mod., 38, n. 2 (2016), pp. 55-105 
MARTA RUIZ SASTRE Y MARÍA LUISA CANDAU CHACÓN

EL NOVIAZGO EN LA ESPAÑA MODERNA Y LA IMPORTANCIA DE LA «PALABRA». TRADICIÓN Y CONFLICTO

mantenían entre sí, contando además con el apoyo familiar, una vez efectuada la promesa, realizadas las capitulaciones o, más sencilla y llanamente, efectuado el compromiso. Según ha quedado de manifiesto, la aceptación popular de este tipo de intimidad se hallaba tan extendida que, muchos años después de Trento, las Constituciones Sinodales de las diferentes diócesis, cuyo espíritu pretendieron trasladar los visitadores en sus inspecciones, con notable esfuerzo y poco éxito, continuaban reiterando el mandato de castidad. Las llegadas de los visitadores -más bien sus salidas- finalizaban casando novios cuyas ceremonias se retrasaban $^{79}$, a veces con métodos tan expeditivos como el encarcelamiento de algunos y sistemas de vigilancia de «comunicaciones» al más puro estilo policial. La venida del visitador, además, era aprovechada para presentar quejas que, de esta forma, no se formalizaron en pleitos: alguna novia embarazada que alegara palabra de casamiento lograría así su deseo ${ }^{80}$, en tanto otros demandados, más poderosos o temidos, se ratificarían en su incumplimiento. Como muestra, nos detendremos en las diligencias realizadas al tiempo de la visita de la villa de Lebrija (Sevilla) por don Pedro González Zurita, visitador general, en el año de 1717. Conocedor de las relaciones mantenidas entre el alcalde ordinario de la villa, don Juan Suárez Tello y Guzmán y doña María de Acevedo, y de los escándalos consecuentes por las continuas entradas y salidas en las casas de la mujer, a quien había dado palabra de casamiento, pese a la desigualdad de las calidades, el visitador atenderá las peticiones de la joven quien, aprovechando su estancia y acudiendo a su amparo, materializará la demanda. He aquí las diligencias:

Pasé a visitarlo a su casa para ver si podía obligarlo con urbanidad y ocultándole las diligencias hechas, le hice el cargo de su decencia, persuadiéndole con razones cristianas y políticas concernientes a la obligación de caballero; mas aunque concedió las entradas y salidas, ...las pretextó con familiaridad... negó ... haberle dado palabra de casamiento y resolvió no casarse ${ }^{81}$.

79. El visitador Curado en pliego secreto remitido a Secretaría de Cámara comentaba, tras su visita a Mairena del Alcor (Sevilla) en 1715, la existencia de capitulados para casarse que andaban remisos en bacerlo. Tras las reprimendas pertinentes aseguraron que lo barian fácil y brevemente. AGAS 1/II.4 Caja 5193 (antigua signatura 2985).

80. Tal narraba el visitador Zurita en su inspección de las parroquias de Utrera, el año de 1715, y enviaba en pliego secreto a Secretaría de Cámara del arzobispado de Sevilla: se presentó doña Inés Jerónima Serrano, moza soltera con petición se llevase adelante una palabra de casamiento que le habia dado Luis Tomás de Saavedra de quien aseguraba estar embarazada de tres meses. La misma noche examiné a dicho Luis Tomás quien en su declaración se conformó con el pedimento de la susodicha. AGAS 1/II.4 Caja 5193 (antigua signatura 2985).

81. Pliego secreto de resultas de visita desta villa de Lebrija... (julio de 1717) remitida por el visitador don Pedro González de Zurita al cardenal Arias, informando de las diligencias realizadas referentes a la relación entre el alcalde ordinario de la villa, don Juan Suárez Tello y

(C) Ediciones Universidad de Salamanca / ®@ Stud. his., H. ${ }^{a}$ mod., 38, n. 2 (2016), pp. 55-105 
MARTA RUIZ SASTRE Y MARÍA LUISA CANDAU CHACÓN

EL NOVIAZGO EN LA ESPAÑA MODERNA Y LA IMPORTANCIA DE LA «PALABRA». TRADICIÓN Y CONFLICTO

Tras el fracaso por la negativa de don Juan -temido por curas y vicario por ser hombre de clase- el visitador remitiría la información al Juez de la Iglesia donde, es de suponer, se tramitaría la demanda.

Las estancias de los visitadores refrescaban a curas y vicarios el cuidado de los «tratados para casar», no importaba el tiempo pasado tras la finalización del Concilio. De este modo: en los tratados para casar cuidan el vicario y los curas de que no frecuenten las casas de sus novias y de que se efectúe el casamiento cuanto antes $^{82}$. Tales anotaciones eran reiteradas visita tras visita, junto a la observancia de las fiestas y el cumplimiento del precepto dominical.

Los pleitos matrimoniales (demandas por incumplimiento de palabra de casamiento) y los criminales (causas por incontinencia) recogieron asimismo la práctica de la intimidad. Dejando al margen los procesos criminales, que no se restringían, obviamente a prometidos o capitulados, los primeros presentaron como prueba de los esponsales contraídos la propia relación carnal. Tanto más de no contar con testimonio notarial, capitulaciones o negociaciones previas reconocidas, porque el trato se convertía en la lógica de la demanda: tan casados estaban que consumaron el matrimonio. El discurso se usaba entonces a la inversa de cualquier lógica posterior: pues nada tendrían que hacer quienes se conservaron doncellas tras los supuestos esponsales; pervertidas las bases del argumento, la doncellez entonces no supondría validez de la palabra de futuro; no había pasado a palabras de presente; la novia que no se otorgaba plenamente a su «marido» no probaba promesa alguna. De ahí que las demandas insistiesen en consumación, relación carnal y... estupro. Esta última imputación dirigida contra el novio buscaba intensificar el efecto en los tribunales eclesiásticos (también civiles), habida cuenta que a los temas del consentimiento mutuo, materializados en la realización de cópula, se añadían los propios de la estimación y la honra. Así, dos fundamentos (eclesiásticos y civiles) se aunaban en la defensa de, sobre todo, las mujeres en los Tiempos Modernos. Si el consentimiento se había otorgado, carnalmente, siguiendo en ello la lógica de la validez del vínculo, su invalidez o su no manifestación pública dejaban sin honor ni estima a la mujer que para demostrar su valor habría de revalidar con pruebas y testimonios su doncellez previa a la palabra de matrimonio. De este modo, los argumentos civiles y eclesiásticos se constituían en justificación sólida del deber del varón: que la mujer usada era mujer sin servicio ni valor; mujer inservible en

Guzmán, y de doña María de Acevedo, y la posterior demanda de matrimonio reclamada por la mujer.

82. Informe de resultas de visitas de Lebrija (Sevilla), 1708, realizado por el visitador general don Juan Vexarano. AGAS 1/II.4. Caja 5175 (antigua signatura, 1347).

(C) Ediciones Universidad de Salamanca / ®@ Stud. his., H. ${ }^{a}$ mod., 38, n. 2 (2016), pp. 55-105 


\section{MARTA RUIZ SASTRE Y MARÍA LUISA CANDAU CHACÓN EL NOVIAZGO EN LA ESPAÑA MODERNA Y LA IMPORTANCIA DE LA «PALABRA». TRADICIÓN Y CONFLICTO}

palabras de una de tantas que se presentaron ante los tribunales demandando matrimonio y honra.

Dos objetivos: demostrar el trato y demostrar la honra. De ahí que -según quedó mencionado- los testimonios a favor de una demanda de matrimonio en beneficio de la mujer reiterasen las virtudes de las, casi siempre, doncellas castas, honestas, modestas, guardadas y sumisas. $\mathrm{O}$, en su caso, de viudas de vida asimismo ejemplar, razón por la cual los argumentos de la literatura y la vida se parecen: que las doncellas burladas por don Juan, o la propia bella Dorotea de Cervantes, en nada se distanciaban de las mujeres de la mayoría de los expedientes. Todas repetían modelos porque todas perseguían un mismo objetivo, lo cual decía mucho del valor del matrimonio, tanto más pleiteado cuanto más se incrementasen las tasas de soltería femenina.

Los testimonios hablarán de la intimidad. No solo de sintetizar con expresiones tales como «entrando y saliendo de las dichas casas», sino de recuerdos de retozos, aislamientos, subidas a la sala u otras manifestaciones del afecto y la sexualidad. En la demanda mantenida por Leonor Mosquera, sevillana, contra el clérigo de menores Alonso de Herrera, en 1617 -en la esperanza de poder interrumpir sus órdenes y acceder al matrimonio-, el testimonio de la criada María Sánchez nos dibuja unas relaciones de noviazgo, alargadas por causa de parentesco, y consentidas por la familia:

Y besaba y abrazaba a la dicha doña Leonor como a su mujer y se subían solos a los altos de la casa y la dicha Leonor se defendía que no quería condescender a la voluntad del dicho Alonso de Herrera cuando la persuadía a que subiese con él a los aposentos y, sin embargo de esto, y de la resistencia de ella, esta testigo los vio subir solos... a una sala en donde tienen una alcoba, donde está una cama... y allí vio acostados a los susodichos, algunas veces solos, aunque estuviesen en la dicha casa los padres ${ }^{83}$.

De igual modo, en el cursado por Violante Rodríguez contra Lázaro Carmona, en 1644, las declaraciones de la madre de la demandante ratificaban un «trato» carnal continuado, hasta el punto de pillar desnudos a los protagonistas en su propia casa; increpando al joven por su comportamiento, su respuesta confirmaba

83. AGAS, Fondo 1. Sección Justicia, Serie Pleitos, leg. 933. Querella por estupro e incumplimiento de palabra de matrimonio contra Alonso de Herrera, clérigo de menores de San Esteban. 1617. Incluye certificado de notario apostólico. Sobre ello, Candau, M. L.: «Emociones y lágrimas. Llantos y lamentos de mujeres», en CANDAU, M. L. (Ed.): Las mujeres y las emociones en Europa y América. Siglos XVII-XIX. Santander, Universidad de Cantabria, 2016.

(C) Ediciones Universidad de Salamanca / ®@ Stud. his., H. ${ }^{a}$ mod., 38, n. 2 (2016), pp. 55-105 
MARTA RUIZ SASTRE Y MARÍA LUISA CANDAU CHACÓN

EL NOVIAZGO EN LA ESPAÑA MODERNA Y LA IMPORTANCIA DE LA «PALABRA». TRADICIÓN Y CONFLICTO

la idea del compromiso: preguntándole que cómo estaba en su casa y echado en la cama le dijo y respondió que estaba con su mujer ${ }^{84}$.

Discursos semejantes -descubiertos o no-usaron todos los varones a juzgar por las demandas de las jóvenes «burladas». Como el comerciante veneciano Francisco Rubín a la joven Jerónima Guzmán, en la Sevilla de, nuevamente, mediados del XVII, a quien traía entretenida con que aguardaba una nao de su tierra con ciertas mercadurías para poder disponer de su casamiento. En el ínterin, y por espacio de más de un año, visitaba y frecuentaba a su supuesta prometida así de día como de noche comiendo y durmiendo con la susodich a como si fueran marido y mujer; tratos que no bastaron; la resolución de sentencia presentaría el desistimiento de la joven, el matrimonio del mercader con otra mujer en Madrid e, intuimos, compensaciones económicas que la consolaran ${ }^{85}$. Como Bartolomé Gallegos y Ana María, vecinos de Triana; él de 23 años, ella de 29. Él embarcando a Indias y retrasando el matrimonio; y ella a la espera, hasta que nuevas amonestaciones en la parroquia le avisaron de las intenciones del supuesto novio de incumplir su palabra. Relatarían entonces los testigos. Y nadie mejor que las parientes de la mujer:

Demás vio que el dicho Bartolomé Gallegos, antes que se fuera en los galeones cuando entraba en casa de esta testigo, abrazaba y besaba a la dicha Doña Ana y porque lo reprendía esta testigo y Juliana de Aldana, madre de la susodicha, el dicho Bartolomé Gallegos decía ¡déjenme señoras que mi mujer ha de ser y yo puedo hacer esto! ${ }^{86}$.

Los argumentos esgrimidos por las demandas, como las negativas de los novios que huyeron del cumplimiento del compromiso, demuestran no solo la fuerza de la palabra, sino de lo que se entendía como su prueba y consumación. Hablaban de relaciones íntimas como algo habitual en el noviazgo, del consentimiento familiar y de las dilaciones a la celebración del matrimonio por causas ajenas, sobre todo, a la voluntad de quienes se creyeron ya desposadas, aun presuntamente. Trabajos, navíos, entretenimientos. También la espera a la llegada de una dispensa por causas de parentesco; no pocas intimidades se continuaron a sabiendas de la familia y vecinos, con la lógica de la promesa contraída y la justificación de la tardanza de las licencias de matrimonios entre los parientes. Porque si bien el IV Concilio de Letrán y luego Trento habían reducido las prohibiciones al cuarto grado -lo que en su día criticaron las iglesias reformadas-, la práctica de la endogamia (sobre todo en las comunidades pequeñas), por causas no solo patrimoniales, retrasaría

84. AGAS, Fondo 1. Sección Justicia, Serie Pleitos Matrimoniales, leg. 4305.

85. Idem, leg. 4336.

86. Idem, leg. 4446. 
MARTA RUIZ SASTRE Y MARÍA LUISA CANDAU CHACÓN

EL NOVIAZGO EN LA ESPAÑA MODERNA Y LA IMPORTANCIA DE LA «PALABRA».

TRADICIÓN Y CONFLICTO

matrimonios, alargando noviazgos y generando relaciones «de hecho» continuadas. La mencionada Leonor Mosquera poseía documentación notarial de la palabra de casamiento otorgada en su día por su pariente Alonso de Herrera. La razón: la espera de una dispensa de parentesco y, claramente, el blindaje de la palabra. Por si acaso. Conociendo el pleito y sus resultados -el desistimiento por presión familiar- no sería suficiente.

El incremento de las demandas de palabra a lo largo del xviI, la continuidad de las relaciones prematrimoniales, el descenso de los matrimonios clandestinos, el fortalecimiento de la autoridad familiar a raíz de las Pragmáticas de fines de siglo, manifiestan la relevancia del matrimonio, y mantienen el conflicto -a nivel eclesiástico- entre libertad y solemnidad, voluntad de los contrayentes y cumplimiento del cuarto mandamiento. A nivel social, el triunfo de la imposición del consentimiento paterno, por lo que vimos no tan difícil de soslayar en el XVII y parte del XVIII, marcaría las distancias; pues si bien las demandas reflejaban -en las sentencias- la «victoria» del orden social, con la evidencia de la promoción de matrimonios en función de la igualdad de la calidad de las familias, la visión otorgada por los matrimonios ordinarios (aquellos que supuestamente no encerraban pleitos) trasluce, también en parte, una realidad conflictiva. Las novias «sacadas» y guardadas en depósito y la rapidez con la que se desenvolvieron las solicitudes de matrimonio en casos de «embarazos» familiares -volvamos, por ejemplo, al matrimonio de la Roldana- presentan realidades aparentemente tranquilas y armónicas al no generar pleitos de huella documental. La vida desde luego no lo confirma. El panorama del proceso matrimonial y los tiempos anteriores a la celebración tampoco.

\section{BibliografíA}

Alcalá Galiano, A.: Memorias. Madrid, 1886.

Arias de SaAvedra, I. y López Guadalupe, M. L.: Vida cotidiana en la Monarquía Hispánica. Tiempos y espacios. Granada, 2015.

Arias de SaAvedra, I. (Coord.): Vida cotidiana en la España de la Ilustración. Granada, 2012.

Baldellou Monclús, D.: «La posición de la mujer ante el matrimonio en las familias aragonesas del siglo XVIII», en Salas Auséns, J. A. (Coord.): Logros en femenino: mujer y cambio social en el valle del Ebro, siglos XVI-XVIII. Zaragoza, 2013, pp. 75-110.

BALdellou Monclús, D.: «Un inesperado recurso. conflictividad social y moral para el acceso al matrimonio en la diócesis de Zaragoza, (s. XVIII)», en SERrano MarTín, E. (Coord.): De la tierra al cielo. Lineas recientes de investigación en Historia moderna. Zaragoza, 2013.

(C) Ediciones Universidad de Salamanca / ®@ Stud. his., H. ${ }^{a}$ mod., 38, n. 2 (2016), pp. 55-105 


\section{MARTA RUIZ SASTRE Y MARÍA LUISA CANDAU CHACÓN EL NOVIAZGO EN LA ESPAÑA MODERNA Y LA IMPORTANCIA DE LA «PALABRA». TRADICIÓN Y CONFLICTO}

Baldellou Monclús, D.: «Cortejo, matrimonio y sentimientos en la España de la Ilustración a través de la correspondencia privada», Obradoiro de Historia Moderna, 23, 2014, pp. 217-248.

Burghartz, S.: «Tales of Seduction, Tales of Violence: Argumentative Strategies before the Basel Marriage Court», German History, 17, 1999, 41-56.

Campo Guinea, M. J.: «Los procesos por causa matrimonial ante el Tribunal Eclesiástico de Pamplona. Siglos XVI y XVII», Príncipe de Viana, 55.

Campo Guinea, M. J.: Comportamientos matrimoniales en Navarra (siglos XVI-XVII). Pamplona, 1998.

Campo Guinea, M. J.: «Evolución del matrimonio en Navarra en los siglos XVI y XvII. El matrimonio clandestino", en Arellano, I. y Usunáriz, J. M.: El matrimonio en Europa y el mundo hispánico. Siglos XVI a XVIII. Madrid, 2005.

Candau Chacón, M. L.: Iglesia y sociedad en la Campiña sevillana. La vicaría de Écija (1627-1723). Sevilla, 1986.

Candau Chacón, M. L.: El clero rural de Sevilla en el siglo XVIII. Sevilla, 1993.

Candau Chacón, M. L.: «Instrumentos de modelación y control: el concilio de Trento y las visitas pastorales. La archidiócesis hispalense, 1548-1609», en MARTínEZ Millán, J. (Ed.):: Felipe II (1527-1598). Europa dividida: la Monarquía Católica de Felipe II. Tomo III Europa y la Monarquía Católica. Inquisición, religión y confesionalismo. Madrid, 1999, pp. 159-179.

Candau Chacón, M. L.: "Adulterio y malos tratos en la archidiócesis hispalense. Siglos XVII y XVIII», en Las mujeres en la Historia de Andalucía. Córdoba, 2002.

Candau Chacón, M. L.: Un mundo perseguido: delito sexual y justicia eclesiástica en los Tiempos Modernos», en Fortea, J. I., Gelabert, E. y Mantecón, T. A. (Coords.): Furor et rabies. Violencia, conflicto y marginación en la Edad Moderna. Santander, 2002, pp. 402-432.

Candau Chacón, M. L.: «Mujer y deseo. La pasión contrariada de una viuda andaluza de fines del Seiscientos», en Espigado Tocino, G., De La Pascua Sánchez, M. J., García-Doncel Hernández, M. R. (Coords.): Mujer y deseo: representaciones y prácticas de vida. Cádiz, 2004, pp. 405-418.

Candau Chacón, M. L.: «Honras perdidas por conflictos de amor: el incumplimiento de las palabras de matrimonio en la Sevilla Moderna. Un estudio cualitativo», Fundación, 7, 2004-2005.

Candau Chacón, M. L.:, «El amor conyugal, el buen amor. Joan Estevan y sus «Avisos de casados», Studia Historica. Historia Moderna. Salamanca, 2005.

Candau Chacón, M. L.: «Otras miradas: el discurso masculino ante el incumplimiento de las promesas de matrimonio. Sevilla, siglos XVII y XviII», en Fuente Pérez, M. J.; López Serrano, A. y Palanco, F. (Coords.): Temas de historia de España: estudios en homenaje al profesor don Antonio Dominguez Ortiz. Madrid, 2005.

Candau Chacón, M. L.: «El matrimonio clandestino en el siglo XVII: entre el amor, las conveniencias y el discurso tridentino», Estudios de Historia de España, 7, 2006, pp. 175-203. 


\section{MARTA RUIZ SASTRE Y MARÍA LUISA CANDAU CHACÓN EL NOVIAZGO EN LA ESPAÑA MODERNA Y LA IMPORTANCIA DE LA «PALABRA». TRADICIÓN Y CONFLICTO}

Candau Chacón, M. L.: «El matrimonio clandestino en el siglo XVII: entre el amor, las conveniencias y el discurso tridentino", Estudios de Historia de España, 8, 2006, pp. 175-202.

Candau chacón, M. L.: «Entre lo permitido y lo ilícito: la vida afectiva en los Tiempos Modernos», Tiempos Modernos. Revista Electrónica de Historia Moderna, Vol. 6, 18, 2009 [En línea].

Candau Chacón, M. L.: «En torno al matrimonio: mujeres, conflictos, discursos», en PeÑa Díaz, M. (Ed.): La vida cotidiana en el mundo hispánico (siglos XVI-XVIII). Madrid, 2012, pp. 97-118.

Candau Chacón, M. L.: «Los Libros de Avisos, fórmula de adoctrinamiento en la Europa Moderna", en Candau Chacón, M. L. (Ed.): Las mujeres y el honor en la Europa Moderna. Huelva, 2014, pp. 29-83.

Candau Chacón, M. L.: «Emociones y lágrimas. Llantos y lamentos de mujeres», en Candau Chacón, M. L. (Ed.): Las mujeres y las emociones en Europa y América. Siglos XVII-XIX. Santander, 2016.

Carballeda, A.: «Género y matrimonio en Nueva España: las mujeres de la elite ante la aplicación de la Pragmática de 1776», en Gonzalbo Aizpuru, P. y Ares Queija, B. (Coords.): Las mujeres en la construcción de la sociedad Iberoamericana. Madrid, 2004.

Casey, J. y Vincent, B.: «Casa y familia en la Granada del Antiguo Régimen», en Casey, J., Chacón, F., Gacto, E., Moll, I., Pla, P. J., Simón, A., Vincent, B.: La familia en la España mediterránea (Siglos XV-XIX). Barcelona, 1987, pp. 94-129.

Casey, J.: Historia de la familia. Madrid, 1990.

Casey, J.: «El matrimonio clandestino en Andalucía en la época moderna», en Familia y sociedad en el reino de Granada durante el Antiguo Régimen. Granada, 2008 (Publicado anteriormente en francés en 1985), pp. 15-35.

Casey, J.: «Le marriage clandestin en Andalousie a l'Époque moderne», en Redondo, A.: Amours légitimes, amours ilégitimes en Espagne (XVI-XVIIe siècles). París, 1985, 57-78. Traducido en Familia y sociedad en el Reino de Granada durante el Antiguo Régimen. Granada, 2008.

Casey, J.: Familia, poder y comunidad en la España moderna. Valencia, 2009.

Castillo Gómez, A.: Entre la pluma y la pared: una historia social de la escritura en los Siglos de Oro. Madrid, 2006.

Celton, D.: «Selección matrimonial y mestizaje en Córdoba», en III Jornadas de Historia de Córdoba, Junta Provincial de Historia de Córdoba, Córdoba, 1990.

Chacón Jiménez, F. y Bestard, J. (Coords.): Familias. Historia de la sociedad española (del final de la Edad Media a nuestros dias). Madrid, 2011.

Ciapelli, G.: «I procesi matrimoniali: quadro di raccordo dei risultati della schedatura», en Seidel Menchi, S. y Quaglioni, D. (Dirs.): I tribunali del matrimonio (secoli $X V-X V I I I)$. Bolonia, 2006, pp. 67-100.

Demerson, J. y Demerson, P.: Sexo, amor y matrimonio en Ibiza durante el reinado de Carlos III. Mallorca, 1993.

(C) Ediciones Universidad de Salamanca / ®@ Stud. his., H. ${ }^{a}$ mod., 38, n. 2 (2016), pp. 55-105 


\section{MARTA RUIZ SASTRE Y MARÍA LUISA CANDAU CHACÓN EL NOVIAZGO EN LA ESPAÑA MODERNA Y LA IMPORTANCIA DE LA «PALABRA». TRADICIÓN Y CONFLICTO}

Dubert García, I.: «Los comportamientos sexuales premaritales en la sociedad gallega del Antiguo Régimen», Studia Historica. Historia Moderna, 9, 1991, pp. 117-142.

Dubert García, I.: «Église, monarchie, mariage et contrôle social dans la Galice rurale XVIIIe et XIXe siècles», Annales de démographie historique, 2, 2009, pp. 101-121.

FAlcón Gómez SÁnchez, F. J.: «El matrimonio clandestino de María Isabel Cavero. Conflicto entre amor, leyes e iglesia, en Truxillo del Peru, a fines del siglo XviII (1794)», en Nuevo Mundo Mundos Nuevos, Debates. [http://www. nuevomundo. revues. org/3352].

Fargas PeÑarrocha, M.: «Ni oírlos ni decirlos. Donde aguardan los secretos, una aproximación a la familia moderna», Cuadernos de Historia Moderna, XIV, 2015, pp. 63-84.

FArge, A.: La vie fragile. Violence, pouvoirs et solidarités à Paris au XVIII siècle. París, 1986.

FERnández, M. A.: Familias en conflicto: entre el honor y la deshonra», Boletín de Estudios de Historia Argentina y Americana, 1999, pp. 7-43.

Ferrante, L.: «Gli sposi contesi. Una vicenda bolognese di metà Cinquecento», en SEIdeL Menchi, S. y Quaglioni, D. (Dirs.).: Matrimoni in dubbio. Unione controverse e nozze clandestine in Italia dal XIV al XVIII secolo. Bolonia, 2001, pp. 329-362.

FLANDRIN, J. L.: La moral sexual en occidente: evolución de las actitudes y comportamientos. 2. ${ }^{\mathrm{a}}$ Ed. Barcelona, 1984 (1. ${ }^{\mathrm{a}}$ ed. en francés, 1981).

Franco Rubio, G. A.: La vida cotidiana en tiempos de Carlos III. Madrid, 2001.

Franco Rubio, G. A. y Pérez Samper, A. (Coords.): «Intimidad y sociabilidad en la España Moderna», monográfico en Revista de Historia Moderna. Anales de la Universidad de Alicante, 30, 2012.

Franco Rubio, G. A.: «Fragmentos de cotidianeidad. Historias de lo cotidiano», Cuadernos de Historia Moderna, 2015, pp. 11-32.

Gálvez Ruiz, M. T.: «La historia de las mujeres y de la familia en el México Colonial», Chronica Nova, 32, 2006, pp. 67-93.

Gálvez Ruiz, M. T.: «Desórdenes y escándalos públicos y notorios en comunidades de México Colonial», en Arias de SAavedra, I. (Coord.): Vida cotidiana en la España de la Ilustración. Granada, 2012, pp. 397-424.

García González, F. (Coord.): La Historia de la familia en la Peninsula Ibérica, balance regional y perspectivas. Albacete, 2008.

García GonzÁlez, J.: «El incumplimiento de las promesas de matrimonio en la Historia del Derecho español», Anuario de Historia del Derecho español, 23, 1953.

García SÁnchez, J.: «Incumplimiento de esponsales: de Roma al derecho vigente», en López Rosa, R.; Pino Toscano, F. (Coords.): El derecho de familia de Roma al derecho actual. Huelva, 2004, pp. 225-270.

Gaudemet, J.: Le mariage en Occident: les moeurs et le droit. París, 1987.

Gaudemet, J.: El matrimonio en occidente. Madrid, 1993.

Ghirardi, M.: Matrimonios y familias en Córdoba. Prácticas y representaciones. Córdoba: Centro de Estudios Avanzados, Universidad Nacional de Córdoba, 2004.

Gómez Carrasco, C. J.: Familia y capital comercial en la Castilla meridional. Madrid, 2009.

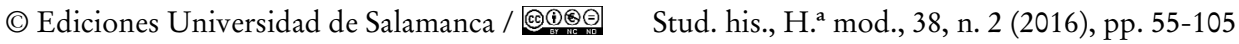




\section{MARTA RUIZ SASTRE Y MARÍA LUISA CANDAU CHACÓN EL NOVIAZGO EN LA ESPAÑA MODERNA Y LA IMPORTANCIA DE LA «PALABRA». TRADICIÓN Y CONFLICTO}

Gonzalbo Aizpuru, P.: «Conflictos y rutinas en la vida familiar», en Gonzalbo Aizpuru, P. (Coord.): Historia de la vida cotidiana en México. El siglo XVIII entre tradición y cambio. Tomo III. Madrid, 2005.

GonzÁlez Gómez, Y. M.: Conflicto, violencia sexual y formas de transgresión moral en el obispado de Concepción, 1750-1890. Tesis doctoral inédita. Departamento de Historia II, Universidad de Huelva, 2011.

Goody, J.: L'Évolution de la famille et du mariage en Europe. París, 1985 (1. a ed. 1983). Goody, J.: La famille en Europe. París, 2001.

Hacke, D.: «La promessa disattesa: il caso di Perina Gabrieli (Venezia 1620)», en SEIdeL Menchi, S. y Quaglioni, D. (Dirs.): Matrimoni in dubbio. Unione controverse e nozze clandestine in Italia dal XIV al XVIII secolo. Bolonia, 2001.

Hernández Bermejo, M. A.: La familia extremeña en los Tiempos Modernos. Badajoz, 1990.

La Rocca, C.: Tra moglie e marito. Matrimoni e separazioni a Livorno nel Settecento. Bolonia, 2009.

LAvrin, A. (Ed.): Sexuality and Marriage in Colonial Latin America. Lincoln \& Londres, 1989.

Lombardi, D.: Matrimoni di Antico Regime. Bolonia, 2001.

Lombardi, D.: Storia del Matrimonio. Bolonia, 2008.

Lorenzo Pinar, F. J.: «Conflictividad social en torno a la formación del matrimonio (Zamora y Toro en el siglo XVI)», Studia Historica. Historia Moderna, 13, 1995, pp. 131-154.

Lorenzo PINAR, F. J.: Amores inciertos, amores frustrados (conflictividad y transgresiones matrimoniales en Zamora en el siglo XVII). Zamora, 1999.

Lozano Corbi, E. A.: «Los esponsales en el Derecho Romano», Anales. Anuario del centro de la UNED de Calatayud, 1, 1993, pp. 145-154.

Luperini, S.: «La promessa sotto accusa (Pisa 1584)», en Seidel Menchi, S. y Quaglioni, D. (Dirs.): Matrimoni in dubbio. Unione controverse e nozze clandestine in Italia dal XIV al XVIII secolo. Bolonia, 2001, pp. 363-394.

Macías Domínguez, A. M.: "Conflictividad matrimonial en el Arzobispado de Sevilla durante la Edad Moderna (siglo XVIII)", en Jiménez Estrella, A.; Lozano Navarro, J. (Eds.): Actas de la XI Reunión Científica de la Fundación Española de Historia Moderna. Granada, 2012, pp. 474-486.

Macías Domínguez, A. M.: El matrimonio, espacio de conflictos: incumplimiento de palabra, divorcio y nulidad en la Archidiócesis Hispalense durante el siglo XVIII. Tesis doctoral inédita. Universidad de Huelva, Departamento de Historia II y Geografía, 2014.

Macías Domínguez, A. M.: «La conflictividad matrimonial bajo control. La intermediación de la comunidad como agente de resolución de conflictos entre casados. Sevilla, siglo xviiI», en Iglesias Rodríguez, J. J., Pérez García, R., Fernández Chaves, M. (Eds.): Comercio y cultura en la Edad Moderna. Actas de la XIII Reunión Científica de la Fundación Española de Historia Moderna. Sevilla, 2015.

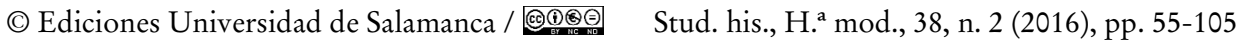




\section{MARTA RUIZ SASTRE Y MARÍA LUISA CANDAU CHACÓN EL NOVIAZGO EN LA ESPAÑA MODERNA Y LA IMPORTANCIA DE LA «PALABRA». TRADICIÓN Y CONFLICTO}

Macías Domínguez, A. M.: «Emociones sobre el papel, cartas de cariño. Relaciones entre novios y desposados a través de sus cartas y billetes (Sevilla, siglo XVIII), en Candau chacón, M. L. (Ed.): Las mujeres y las emociones en Europa y América. Siglos XVII-XIX. Santander, 2016.

Macías Domínguez, I. y Morales Padrón, F.: Cartas desde América, 1700-1800. Sevilla, 1991.

Mantecón Movellán, T. A.: «Desviación, disciplina social e intervenciones judiciales en el Antiguo Régimen», Studia Historica. Historia Moderna, 14, 1996, pp. 223-248.

Mantecón Movellán, T. A.: Conflictividad y disciplinamiento social en la Cantabria rural del Antiguo Régimen. Santander, 1997.

Mantecón Movellán, T. A.: «El mal uso de la justicia en la Castilla del siglo XviI», en Fortea, J. I., Gelabert, E. y Mantecón, T. A. (Coords.): Furor et rabies. Violencia, conflicto y marginación en la Edad Moderna. Santander, 2002.

Mantecón Movellán, R.: «Cartas de amor y silencios: la correspondencia privada entre Buenos Aires y España en el siglo XVIII", Fundación, 7, 2004-2005, pp. 229-242.

Mantecón Movellán, R. y Candau Chacón, M. L.: «Las otras mujeres de América: las esclavas negras en tiempos de la Colonia. Un estudio a través de la correspondencia privada», en Valero, S.: Negritud, estudios afrolatinoamericanas. Cartagena, Colombia, 2014, pp. 213-235.

Manzoni, A.: Los novios. Madrid, 1985 (1. ${ }^{\mathrm{a}}$ ed. 1827).

Márquez Macías, R.: Historias de América: la emigración española en tinta y papel. Huelva, 1994.

MÁRquez Macías, R.: «Cartas de mujeres emigrantes: nostalgia y recuerdos (siglos XVIIIxix)», en Chivite de León, M. J., Hernández Pérez, M. B., Monzón Perdomo, M. E. (Coords.): Frontera y género: en los límites de la multidisciplinariedad. Madrid, 2011, pp. 171-185.

Márquez Macías, R.: «El amor y el olvido en la correspondencia privada de los emigrantes en América», en Castillo, A., Sierra, V. (Eds.): Cinco siglos de cartas. Historia y prácticas epistolares en las Épocas moderna y contemporánea. Huelva, 2014, pp. 275-290.

Marre, D.: «La aplicación de la Pragmática Sanción de Carlos III en América Latina: una revisión», en Scipta Vetera. [http//: www.ub.es.geocrit/sv-22htm (17-10-2002)].

Martínez Martínez, M. C.: Desde la otra orilla: cartas de Indias en el Archivo de la Real Chancillería de Valladolid (siglos XVI-XVIII). León, 2007.

Mоnтото, S.: «El casamiento de la Roldana», Boletín de la Academia Sevillana de Buenas Letras, 15, 1920, pp. 113-120.

Monzón Perdomo, M. E.: «La familia como espacio de conflicto. Los juicios por disenso matrimonial en Tenerife», Anuario de estudios Atlánticos, 60, 2014, 413-450.

Morant Deusa, I. y Bolufer Peruga, M.: «El matrimonio en el corazón de la sociedad», Tiempos Modernos, 2009.

Morant Deusa, I.: Discursos de la vida buena. Madrid, 2002.

(C) Ediciones Universidad de Salamanca / ®@ Stud. his., H. ${ }^{a}$ mod., 38, n. 2 (2016), pp. 55-105 


\section{MARTA RUIZ SASTRE Y MARÍA LUISA CANDAU CHACÓN EL NOVIAZGO EN LA ESPAÑA MODERNA Y LA IMPORTANCIA DE LA «PALABRA». TRADICIÓN Y CONFLICTO}

Navarro Bonilla, D.: Del corazón a la pluma. Archivos y papeles privados femeninos en la Edad Moderna. Salamanca, 2004.

Ortega López, M.: «Protestas de las mujeres castellanas contra el orden patriarcal privado durante el siglo XVIII», Cuadernos de Historia Moderna, 19, 1997, pp. 67-89.

Ortega López, M.: «Género e historia moderna: una revisión a sus contenidos», Contrastes. Revista de Historia, 11, 1998-2000.

Ortega López, M.: «Violencia familiar en el pueblo de Madrid durante el siglo XVIII», Cuadernos de Historia Moderna, 31, 2006, pp. 7-37.

Ortego Agusín, M. A.: Familia y matrimonio en la España del siglo XviII. Ordenamiento jurídico y situación real de las mujeres a través de la documentación notarial. Tesis doctoral. Departamento de Historia Moderna. Universidad Complutense, Madrid, 1999.

Oтte, Enrique. Cartas privadas de emigrantes a Indias, 1540-1616. Sevilla, 1988.

Parente, U. y Scaramella, P.: «I processi matrimoniali napoletani (secoli XVI-XVII)», en Seidel Menchi, S. y Quaglioni, D. (Dirs.): I tribunali del matrimonio (secoli XV-XVIII). Bolonia, 2006, pp. 163-188.

Pascua Sánchez, M. J. de la: Mujeres solas. Historias de amor y abandono en el mundo bispánico. Málaga, 1998.

Pascua Sánchez, M. a J. de la: «Una aproximación a la historia de la familia como espacio de afectos y desafectos: el mundo hispánico del Setecientos», Chronica nova, 27, 2000, pp. 131-166.

Pascua Sánchez, M. ${ }^{a}$ J. de la: «La recuperación de una memoria ausente: demandas judiciales y relatos de vida en la construcción de la historia de las mujeres», Arenal. Revista de historia de mujeres, 12, 2, 2005, pp. 211-234.

Pascua SÁnchez, M. J J. de la: «Las relaciones familiares: historias de amor y conflicto», en Morant Deusa, I. (Coord.): Historia de las mujeres en España y América Latina, Vol. 2. Madrid, 2005, pp. 287-316.

Pascua Sánchez, M. ${ }^{a}$ J. de la: «Regulación de los afectos y la cultura del amor en la sociedad hispana de la época Moderna», en Iglesias Rodríguez, J. J., Pérez García, R., Fernández Chaves, M. (Eds.): Comercio y cultura en la Edad Moderna. Actas de la XIII Reunión Científica de la Fundación Española de Historia Moderna. Sevilla, 2015.

Peña Díaz, M: La vida cotidiana en el mundo hispánico (siglos XVI-XVIII). Madrid, 2012.

Pineda Alfonso, J. A.: El gobierno del tribunal arzobispal de Sevilla en el siglo XVII. Tesis doctoral inédita. Departamento de Historia Moderna. Defendida en diciembre de 2015.

Pla Alberola, P. J.: «Familia y matrimonio en la Valencia Moderna. Apuntes para su estudio», en Casey, J., Chacón, F., Gacto, E., Moll, I., Pla, P. J., Simón, A., VInCEnT, B.: La familia en la España mediterránea (Siglos XV-XIX). Barcelona, 1987, pp. 94-129.

PoIAn, M.: «I processi matrimoniali dell'Archivio Vescovile di Feltre (secoli XVI-XVIII)», en Seidel Menchi, S. y Quaglioni, D. (Dirs.): I tribunali del matrimonio (secoli $X V-X V I I I)$. Bolonia, 2006, pp. 141-161.

(C) Ediciones Universidad de Salamanca / ®@ Stud. his., H. ${ }^{a}$ mod., 38, n. 2 (2016), pp. 55-105 


\section{MARTA RUIZ SASTRE Y MARÍA LUISA CANDAU CHACÓN EL NOVIAZGO EN LA ESPAÑA MODERNA Y LA IMPORTANCIA DE LA «PALABRA». TRADICIÓN Y CONFLICTO}

Porro, N.: «Conflictos sociales y tensiones familiares en la sociedad virreinal rioplatense a través de los juicios de disenso", Boletín del Instituto de Historia Argentina y Americana, 26, 1980, pp. 361-393.

Porro, N.: «Extrañamientos y depósitos en los juicios de disenso», Revista de Historia del Derecho, 7, pp. 123-150.

Porro, N.: «Los juicios de disenso en el Río de la Plata: Nuevos aportes sobre la aplicación de la Pragmática de hijos de familia», Anuario Histórico y Jurídico Ecuatoriano, 5, pp. 193-229.

Ramos Cobano, C.: La familia en femenino. Prácticas sociales y relaciones de género entre los Cepeda en el tránsito a la Contemporaneidad. Madrid, 2016 (En prensa).

Rey Castelao, O. y Rial García, S.: Historia de las mujeres en Galicia, siglos XVI al XIX. Vigo, 2009.

Rey Castelao, O.: «Las respuestas sociales a la pobreza femenina en la España de la Ilustración. Algunas notas», en Lobo de Araujo M. M., Esteves, A. (Coords.): Marginalidade, pobreza e respostas sociais na Península Ibérica (séculos XVI-XX). Braga, 2011.

Rey Castelao, O.: «Las mujeres gallegas y el honor», en Las mujeres y el honor en la Europa moderna. Huelva, Universidad, 2014.

Rípodas Ardanaz, D.: El matrimonio en Indias. Realidad social y regulación jurídica. Conicet, Buenos Aires, 1997.

Ruiz Sastre, M.: Matrimonio, moral sexual y justicia eclesiástica en Andalucía Occidental: la Tierra Llana de Huelva (1700-1750). Sevilla, 2011.

Ruiz Sastre, M. y Macías Domínguez, A. M.: «La pareja deshecha. Pleitos matrimoniales en el Tribunal Arzobispal de Sevilla durante el Antiguo Régimen», Erebea. Revista de Humanidades y Ciencias Sociales, 2, 2012, pp. 291-320.

Ruiz SASTRE, M.: «Vidas unidas contra el discurso tridentino. El matrimonio clandestino en la Sevilla del Seiscientos», en Las mujeres y el honor en la Europa Moderna. Huelva, 2014, pp. 243-270.

Ruiz Sastre, M.: Mujeres y conflictos en los matrimonios de Andalucía occidental. El Arzobispado de Sevilla durante el siglo XVII. Tesis doctoral, Departamento de Historia II y Geografía, Facultad de Humanidades, Universidad de Huelva, 2016.

SEed, P.: To Love, Honor, and Obey in Colonial Mexico. Conflicts over Marriage Choice 1574-1821. Stanford, 1988.

Seidel Menchi, S.: «I processo matrimoniali come fonte storica», en Seidel Menchi, S. y Quaglioni, D. (Dirs.): Coningi nemeci. La separazione in Italia dal XII al XVII secolo. Bolonia, 2000, pp. 15-94.

Seidel Menchi, S. y Quaglioni, D. (Dirs.).: Matrimoni in dubbio. Unione controverse e nozze clandestine in Italia dal XIV al XVIII secolo. Bolonia, 2001.

Seidel Menchi, S. y Quaglioni, D. (Dirs.): «La Svoltadi Trento. RicercheItaliane sui processimatrimoniali», Popolazione e Storia, 2, 2004, 21-31.

Seidel Menchi, S. y Quaglioni, D. (Dirs.): Transgressioni. Seduzione, concubinato, adulterio, bigamia (XIV-XVIII secolo). Bolonia, 2004.

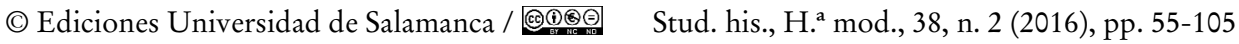


Seidel Menchi, S. y Quaglioni, D. (Dirs.): I tribunali del matrimonio (secoli XV-XVIII). Bolonia, 2006.

Socolow, S.: «Parejas bien constituidas. La elección matrimonial en la Argentina colonial. 1778 -1810», en Anuario del Instituto de Estudios Históricos y Sociales. Tandil, 1997.

STANGL, W.: «Un cuarto de siglo con cartas privadas de emigrantes a Indias. Prácticas y perspectivas de ediciones de cartas transatlánticas en el Imperio español», en Anuario de Estudios Americanos, 70, 2, 2013, pp. 703-736.

Testón Nuñez, I. y SÁnchez Rubio, R.: El hilo que une: las relaciones epistolares en el Viejo y Nuevo Mundo (siglos XVI-XVIII). Cáceres, 1999.

Testón Nuñez, I.: Amor, sexo y matrimonio. Badajoz, 1985.

Torremocha Hernández, M. y Drumond Braga, I. (Coords.): As mulheres perante os tribunais do Antigo Regime na Península Iberica. Coimbra, 2015.

Usunáriz Garayoa, J. M.: Una visión de la América del xviII. Correspondencia de emigrantes guipuzcoanos y navarros. Madrid, 1992.

UsunÁRIZ GARAYOA, J. M.: «Sentimientos e historia. La correspondencia amorosa en los siglos XVI-XVIII», en Castillo, A. y Sierra, V. (Eds.): Cinco siglos de cartas. Historia y prácticas epistolares en las Épocas moderna y contemporánea. Huelva, 2014.

(C) Ediciones Universidad de Salamanca / @®@@ Stud. his., H. ${ }^{a}$ mod., 38, n. 2 (2016), pp. 55-105 
